\title{
Series documentales para la investigación en historia de las universidades
}

\author{
Agustín Vivas Moreno \\ Guadalupe Pérez Ortiz *
}

Artículo recibido:

28 de febrero de 2011.

Artículo aceptado:

3 de octubre de 2011.

\section{RESUMEN}

El presente trabajo tiene por objeto estudiar y clasificar las series documentales de utilidad para la investigación en historia de las universidades. Para ello partimos del análisis de la institución universitaria para posteriormente examinar la evolución de la archivística universitaria. En tercer lugar proponemos una clasificación documental para la documentación histórica de las universidades basada en la metodología institucional, y por último realizamos un análisis exhaustivo de las series documentales del Estudio Salmantino, de aplicación en la inmensa mayoría de las universidades hispanas. Cuatro conclusiones, relativas a cada una de las partes expuestas, ponen fin a nuestra investigación.

* Ambos autores pertenecen a la Universidad de Extremadura, España. (Agustín: avivas@alcazaba.unex.es); (Guadalupe: mgperort@alcazaba.unex.es).

INVESTIGACIÓN BIBLIOTECOLÓGICA, Vol. 25, Núm. 55, septiembre/diciembre, 2011, México, ISSN: 0187-358X. pp. 13-66 
Palabras clave: Archivos universitarios; Clasificación documental; Historia de las universidades; Universidades.

\begin{abstract}
Documentary series for research in history of universities

Agustín Vivas Moreno and Guadalupe Pérez Ortiz

The present work takes as its object the study and classification of the useful documentary series for the investigation in history of universities. For that purpose, we part from the analysis of the university institution, later, we examine the evolution of the university archivistics. In the third place, we propose a documentary classification for the historical documentation of the universities, based on the institutional methodology. Finally, we make an analysis of the documentary series of the Salamancan Study applicable in the majority of Hispanic universities. Four conclusions, related to each of the exposed parts, put an end to our investigation.
\end{abstract}

Keywords: University files; Documentary classification; History of universities; Universities.

$\mathrm{N}^{\circ}$ o cabe duda alguna de que los archivos universitarios son uno de los sectores más dinámicos en el panorama profesional de los últimos años en España. La progresión de que han gozado durante las últimas décadas resulta ser admirable y la casi totalidad de las Universidades españolas han efectuado mejoras efectivas en los diferentes ámbitos vinculados. En este sentido quizás convenga especificar ya que entendemos el archivo universitario como un sistema de información constituido por uno o más conjuntos orgánicos de documentos, producidos, recibidos o acumulados naturalmente por la institución universitaria en el ejercicio de sus funciones, actividades y procedimientos; conjuntos reunidos, organizados y conservados mediante principios y metodología científica como garantía de derecho y de fuente de información.

Antes de seguir quizás convenga anteponer una matización ante posibles desasosiegos. Si de investigación en historia de las universidades hablamos, 
debemos dejar claro que, en nuestro intento de sistematización clasificatoria para analizar las series documentales, haremos únicamente referencia a la documentación histórica que se custodia en los archivos universitarios. Y ello sin pretender contradecir el modelo integral del servicio de archivos, que debe abarcar los documentos generados y recibidos por toda la estructura organizativa universitaria y que, del mismo modo, debe gozar de competencias sobre documentos de cualquier edad. No se trata, en consecuencia, de establecer un modelo historicista centrado únicamente en los fondos más antiguos de la institución, si bien es planteable el hecho de que en universidades grandes y de gran tradición histórica, hasta no diseñarse un modelo integral de forma concluyente, pueda franquearse un modelo mixto. ${ }^{1}$ En definitiva entendemos que la clasificación de la documentación histórica no contradice la potencial clasificación genérica de todos los fondos — que defendemos-, sino que simplemente es un instrumento más para fortalecer el proceso informativo-documental y facilitar la investigación en la historia de las universidades. Dicho modelo de clasificación, eso sí, deberá ser funcional y fácilmente acomodaticio al modelo integral futuro. ${ }^{2}$

Dicho esto, antes de adentrarnos en el análisis minucioso de las series documentales que son de utilidad para la investigación en historia de las universidades, quizás convenga especificar cuáles serán los apartados en los que segmentaremos nuestra contribución:

1 Este ha sido un tema discutido y, según qué tipología de archivos, recurrente en la historiografía archivística, tanto, que a nadie debiera escandalizar su atención teórica. El modelo mixto no como un fin en sí mismo sino como paso metodológico hasta llegar a un modelo integral. (Por ejemplo, para archivos municipales, vid. Alberch i Fugueras, R. Els arxius historics municipals: normed basiques de classificació, Barcelona, 1962 donde se especifica una clasificación para la documentación histórica que ha servido para la posterior Normes per a la classificació de la Documentació Municipal, (Barcelona, 1989); las reflexiones de Fernández Hidalgo, M ${ }^{a}$ del C. y García Ruipérez, M. "La clasificación en los archivos municipales españoles: evolución histórica y situación actual”, en Irargi. Revista de Archivístic, II (1989), pp. 133-349), o las consideraciones iniciales de matices teóricos del propio Grupo de Archiveros Municipales de Madrid al realizar su Cuadro de Clasificación, las reflexiones de la Mesa de Archivos Municipales de la Comunidad Valenciana o el Manual de la Asociación de Archiveros franceses (Manuel d'Archivistique. París, 1970)). En definitiva, somos firmes defensores de un único cuadro de clasificación que sirva a la gestión administrativa y a la investigación en Historia de las Universidades, entendiendo que todas las aportaciones son útiles para lograr ese empeño, máxime en instituciones de largo tiempo, donde la documentación histórica presenta un valor añadido. Con otras palabras, la presencia de dos modelos — sistema mixto- en una institución como la Salmantina, por ejemplo, resulta ser, a nuestro entender, un método efectivo para lograr el establecimiento de un modelo integrado que configurara un sistema global de intervención en la documentación y los archivos que convenimos que es lo más pertinente y acertado.

2 Vid. el cuadro de clasificación que propusimos para la documentación histórica de la Universidad de Salamanca en A. Vivas Moreno El Archivo Histórico de la Universidad de Salamanca. Historia y clasificación de sus fondos documentales, Gijón: Trea, 2003. Desde un punto de vista historicista, vid. el interesante trabajo de M. Peset Reig, "Los archivos universitarios: su contenido y sus posibilidades", en Estudios en recuerdo de la profesora Sylvia Romeu Alfaro, Valencia: Universidad, 1989, T. II, pp. 759-772. 
- en primer lugar es apropiado realizar, a modo de introducción, un escueto estudio de la institución productora de la documentación, cuestión imprescindible para un correcto análisis documental y archivístico. En este sentido, es por todos conocido como sólo tras un conocimiento de la institución podremos comprender la clasificación de la documentación emanada del ejercicio de sus funciones, actividades y procedimientos administrativos. Asimismo, realizaremos un esbozo telegráfico de la evolución de la historia de la archivística universitaria, lo que nos permitirá entrever los períodos más significativos de su progresión;

- en segundo lugar, expondremos un modelo de clasificación hipotética para la documentación histórica, correspondiente a la emanada por las Universidad Mayores de la Monarquía Hispánica (Salamanca, Alcalá y Valladolid);

- por último, en forma de tablas, analizaremos las series de mayor relevancia ubicadas en los fondos históricos universitarios, y que consideramos de especial utilidad para la investigación en Historia de las Universidades. Para ello nos centraremos en el examen del fondo histórico del Estudio salamantino, exponente máximo del modelo clásico universitario en el Antiguo Régimen Hispano.

- unas breves conclusiones y una sencilla y concisa bibliografía con la que complementar lo aquí esbozado pondrá fin al capítulo.

\section{INTRODUCCIÓN}

\subsection{La institución productora}

Nos insertamos a continuación en una labor que podríamos calificar como difícil intentar exponer en unos párrafos las diferentes etapas que marcan la evolución histórica de la Universidad. Y ello no sólo por el largo tiempo de la institución sino también por sus profusas posibilidades de estudio y comprensión, la complejidad y dinamismo institucional en el que se ha visto envuelto, o la consabida formalización de un paradigma organizativo y referencial que se proyectará hacia el exterior durante los siglos modernos. La clasificación documental, por todos sabida, necesita del conocimiento institucional. De este modo nuestro cometido aquí no es otro que el de exponer a modo de esquema aquellos períodos que entendemos que acaban determinando el desarrollo histórico de la institución, y que suponemos como indispensables o de amplia rentabilidad para la comprensión de las respectivas 
funciones, actividades y procedimientos. Cinco son las etapas en las que podríamos segmentar la historia de nuestra institución: ${ }^{3}$

1) Etapa Medieval o de afianzamiento (ss. XIII-XV)

En este período la Universidad tiene como característica principal su regionalización, esto es, la vinculación de las universidades emergentes a los reinos. En el marco del renacimiento urbano del s. XII, donde tienen lugar las asociaciones gremiales, surge la universidad como corporación de los dedicados al aprendizaje institucional (universitas magistrorum et scholarium) apoyados en el derecho canónico y romano, la consolidación de un método dialéctico y en el derecho de admisión y aprobación de los aprendices, mediante una licencia o graduación. Con las continuas protecciones pontificia y regia, la Universidad acaba deviniendo en una institución docente con otorgamiento de grados reconocidos. En Castilla, las universidades ciñen vinculaciones pujantes con la Curia y convierten al Papa, hasta las pautas de intervención monárquica de los Reyes Católicos, en referente de la consolidación universitaria. Por su parte, en Aragón las Universidades presentan una mayor vinculación con las oligarquías locales.

2) Etapa Moderna o de clasicismo (ss. XVI-XVIII)

La Universidad supera su ámbito regional y resultan ser Salamanca, Valladolid y Alcalá verdaderas Universidades Mayores de la Monarquía Hispánica. Se trata de universidades al servicio del Estado Moderno recién instaurado y de la Iglesia católica, además de gozar de una amplia proyección para las Indias hispanas. De ocho universidades con grados reconocidos en 1475 se pasa a treinta y dos hacia 1625. Los poderes monárquicos, a través del Consejo de Castilla esencialmente, intervendrán decididamente en la expansión universitaria reseñada y formarán el personal especializado para la administración, la burocracia y los tribunales de justicia. Asimismo, la Universidad resulta ser un instrumento para la defensa de la fe y sus alumnos altos cargos para la administración eclesiástica. Más adelante las Reformas ilustradas acrecentarán el control monárquico que, con la expulsión de los jesuitas, quedará claramente ejemplificado. Por su parte los Colegios Mayores se convierten en grupos de presión de carácter endogámico

3 Vid., L.E. Rodríguez-San Pedro Bezares, "La Universidad de Salamanca, evolución y declive de un modelo clásico", en Studia Histórica.Historia Moderna IX, 1991, 9-21; Ibidem "Las Universidades de Castilla", en Historia de una cultura: la singularidad de Castilla, Valladolid: Junta de Castilla y León, 1995, Tomo II, pp. 411-459; Ibídem, "Universidades en Castilla y León", Tomo IV, pp. 403-423; Vivas Moreno, A., El Archivo Histórico de la Universidad de Salamanca: bistoria y clasificación de sus fondos documentales, Gijón: Trea, 2003. 
con el consiguiente aislamiento de los estudiantes manteístas, y los catedráticos de propiedad en una inaccesible oligarquía, lo que supone obtener jerarquías y prerrogativas, y operar las instituciones en su conveniencia.

3) Etapa contemporánea y centralista (s. XIX-XX)

En este período la Universidad tradicional quiebra y vuelve a regionalizarse, convirtiéndose de nuevo en universidades de distrito. Muere el modelo clásico universitario y surge el modelo burocrático, liberal y centralista que subsistirá en sus tonos hasta bien entrado el s. XX. El Plan caballero de 1807, las continuas alternativas de reformas liberales y las restauraciones absolutistas al ritmo de los cambios políticos, el Plan Pidal de 1845 y, definitivamente, la Ley Moyano de 1857 ocasionará que la Universidad deje los fundamentos tradicionales que la habían caracterizado para regirse y organizarse siguiendo los moldes liberales. Son características de este momento la dependencia de las Universidades del entonces Ministerio de Fomento, la designación de los rectores por parte del Ministro de turno, la creación del cuerpo de funcionarios catedráticos de carácter nacional y con oposiciones centralizadas, la creación de seis facultades superiores - ciencias exactas, físicas y naturales, farmacia, medicina, derecho y teología-, o la organización de las universidades en diez distritos, con uno de ellos centralizado en Madrid que reglaba prácticamente la organización administrativa. Más adelante se promulga la Ley de Ordenación Universitaria de julio de 1943, la cual mantendría su vigencia hasta la de Villar Palasí en 1970. Naturalmente la universidad quedó supeditada a la dogmática ideología del nacional-catolicismo, la Falange y los principios del Movimiento. Aparece, eso sí, una nueva facultad, la de ciencias políticas y económicas.

4) La expansión universitaria (s. XX)

Como hemos visto, tras la guerra civil, la universidad queda configurada como una universidad centralista y un destacado control político y administrativo. La Ley Villar Palasí de 1970 trajo consigo una cierta apertura al espacio universitario, esencialmente en lo correspondiente a docencia e investigación, fundamentadas en el impulso de los departamentos y los institutos universitarios, lo que ocasionó entre otros elementos la aparición de asignaturas optativas. Asimismo reaparecen los claustros con ciertas capacidades a nivel institucional. Más adelante, con la Ley de Reforma Universitaria (LRU) de 1983, se configura una etapa que termina definitivamente con los restos de modelo liberal, y se instaura un nuevo modelo de autonomía universitaria que 
incluye importantes cambios y novedosas tendencias. Surge a partir de entonces un nuevo modelo de descentralización basado en el marco de las Comunidades Autónomas con las consiguientes colisiones con el marco heredado centralista. La universidad en este nuevo segmento se regionaliza en relación con el entorno más cercano. Surgen riesgos fundamentados de provincianismo, clientelismo y endogamia ante las oligarquías más cercanas. En definitiva, las universidades pierden influencia a medida que nos alejamos del lugar. Cuatro podrían ser las características de la universidad de la segunda mitad del s. XX: un incremento de universidades sin precedente, una diversificación de facultades y titulaciones, un fuerte incremento de alumnos con una multitudinaria presencia femenina en las aulas, y masivas contrataciones de profesores no numerarios (PNN) y su posterior funcionarización a partir de 1983 con las "pruebas de idoneidad" y la consiguiente imposibilidad de incorporar a los alumnos de mejor expediente a través de las, entonces, difíciles de obtener becas de investigación. En conclusión, en estos años se da el viraje de una corriente centrípeta liberal hacia otra centrífuga, y si la primera presentaba claros inconvenientes administrativos y de control, la segunda presenta una configuración demasiado localista acorde con los institutos provinciales decimonónicos. La Universidad pasa a depender en demasía de los poderes políticos más cercanos con lo que pierde una dosis de independencia y gana en docilidad.

5) Elproyecto homogeneizador europeo

Con la Declaración de Bolonia de junio de 1999 y el establecimiento del área europea de Educación Superior, entiendo que se abre una nueva etapa histórica de la institución universitaria en la que nos encontramos inmersos con amplias potencialidades e incertidumbres. La homogenización de la oferta educativa, el reconocimiento de estudios a nivel europeo, el incremento de la competitividad y todas sus consecuencias en el marco universitario, el salto de una cultura centrada en la oferta a otra basada en la demanda, la transformación del teaching al learning y la movilidad estudiantil y del profesorado podrían ser algunas de las características que presenta el nuevo Espacio Europeo de Educación Superior. Asistimos en consecuencia a una regeneración de conocimientos que ofrece nuevas perspectivas, en perjuicio de las soluciones humanistas e integradoras que habían caracterizado los modelos clásico y liberal universitarios. Son las necesidades operativas, la demanda ejecutante del mercado, la búsqueda de la rentabilidad y los formalismos técnicos los que caracterizan 
este nuevo ámbito que se nos abre, y todo ello en el marco de amplios grupos de investigación que son gestionados como sociedades empresariales. En síntesis, la reforma boloñesa se articula en tres aspectos básicos: facilitar la movilidad estudiantil y laboral, estructurar los planes de estudio en tres niveles: grado, master y doctorado, y cuantificarlos mediante los llamados créditos europeos (ECTS) para valorar así el esfuerzo real del estudiante en superar las distintas materias. Y con todo, un mayor componente práctico y una búsqueda de competencias concretadas en conocimientos, habilidades y destrezas para afrontar con garantías la práctica profesional. En definitiva, frente a la integración humanista, la profesionalización de los estudios universitarios con tintes neoliberales según algunos. Quedan por ver las consecuencias reales de esta trascendente reforma que persigue un modelo europeo unificado.

\subsection{Características generales de la archivistica universitaria}

Nos proponemos ahora establecer una escueta periodización para la historia de la archivística universitaria que atendiendo de forma sustancial al concepto mismo de archivo universitario, no ignore el contexto institucional y cultural. Así, de forma didáctica hemos establecido tres grandes etapas que deben ser manejadas con la cautela de lo que pretende ser una categorización historiográfica:

- La Archivística universitaria como doctrina jurídico-administrativa, que abarcaría desde las fundaciones universitarias hasta la segunda mitad del s. XVIII.

- La Archivística universitaria como desarrollo bistoriográfico, que llegaría desde la segunda mitad del siglo XVIII, hasta la primera mitad del s. XX.

- Y por último la Archivística actual que abarcaría los importantes avances habidos en las últimas décadas.

Veamos brevemente y de forma casi esquemática lo que podrían ser las características elementales de cada uno de estos períodos.

\section{1) La archivística universitaria como doctrina jurídico-administrativa}

Los archivos universitarios se remontan, sin duda alguna, a los tiempos fundacionales de las Universidades. En los primeros momentos universitarios los documentos son custodiados siguiendo una archivística puramente inductiva, caracterizada por la ausencia de un cor- 
pus teórico archivístico reconocido como tal. Nos referimos fundamentalmente a documentos claustrales — función docente- y de las autoridades gubernativas universitarias y extrauniversitarias - Pontífice, Rey, Rector. En estos momentos no existe especulación archivística específica, sino que los métodos de clasificación y ordenación de documentos son el resultado de una elemental práctica funcional. El producto, por tanto, es el de una simple práctica empírica guiada por la lógica. Aunque ciertamente los datos con los que contamos son muy minoritarios para esta etapa, parece que se alcanza paulatinamente una inserción del archivo en el contexto institucional universitario y representativo, y se suscitan expectativas de evidencia documental y vigencia jurídica. En definitiva el archivo irá quedando convertido en el lugar donde se conservan los monumentos escritos, con existencia propia e independiente, y con el objeto de testimoniar los negocios administrativos y jurídicos.

El período que propiamente pretendemos describir, siquiera someramente, es aquél donde la archivística se desarrolla como una doctrina patrimonial y jurídica al servicio de la institución universitaria. El archivo se convirtió en un elemento fundamental de la maquinaria institucional y administrativa universitaria y, por tanto, adquirió una función predominantemente jurídico-política, al ofrecerles a los matriculados una documentación útil para la afirmación de sus derechos, y para el ejercicio de sus privilegios y prerrogativas. Es éste un proceso lento que tiene su inicio en la Baja Edad Media, cuando las Universidades Hispánicas tienen su esplendor durante la segunda mitad del s. XVI, y que alcanzará hasta el s. XVIII, teniendo su contexto globalizador en el desarrollo de la administración, el incremento de la burocratización y la regularización, y la presencia de funcionarios profesionalizados con obligaciones gubernativas y judiciales, que justamente comenzaban a emerger de las grandes universidades castellanas.

Veamos muy brevemente lo que podrían ser las características para este período:

- El archivo como doctrina jurídica al servicio de la administración universitaria, esto es, y para no reiterarlo más, como instrumento administrativo. Asimismo, y en consecuencia, hay una mejora de las técnicas de tratamiento archivístico. De este modo comienzan a darse algunas reglamentaciones en los diferentes Estatutos y Constituciones sobre la conservación de los documentos fundacionales, privilegios jurisdiccionales y documentación, 
que estipulan dotaciones económicas para el sostenimiento de la institución. Se trata de los denominados Archivos Universitarios Antiguos que frecuentemente se custodiaban en el Arca del Tesoro o Caudales. ${ }^{4}$

- Desarrollo de la organización administrativa universitaria y complejidad de la práctica documental. El incremento de las universidades peninsulares, la importante cantidad de recursos económicos de que disponen en algunos casos, la complejidad institucional y administrativa que logran, la recuperación del derecho Romano y del procedimiento administrativo que lo sostenía -junto a la conformación del Estado Absoluto que le da cobijo-, hicieron factible la rehabilitación del documento como fundamento de la organización universitaria. Como consecuencia de todo ello, el Archivo quedó transformado en el instrumento base de la organización administrativa de las Universidades, tal y como se refleja en los diferentes Estatutos que se formalizan. En definitiva, creciente complejidad administrativa y burocratización progresiva, que se traducían en una práctica documental cada vez más embarazosa. Se trata de la documentación universitaria administrativa o del claustro de la Universidad, regenteada por el secretario y reglamentada en su conservación y en su ubicación por los correspondientes Estatutos.

- Archivo de la autoridad universitaria. Consideramos que el archivo universitario, si bien de forma calmosa, acaba resultando ser uno más de los mecanismos de poder de los órganos de gobierno universitarios, esto es, uno de los procedimientos de dominio y control. El archivo, pues, como atributo de los órganos de poder universitario, de carácter inescrutable e inaccesible. ${ }^{5}$

- Incipiente desarrollo de instrumentos de descripción archivísticos universitarios. Desde finales del s. XVI y a lo largo de los siglos XVII y XVIII surgen paulatinamente instrumentos archivísticos que pretenden, de una u otra forma, describir los documentos

4 Vid para este apartado, entre otros, por su relevancia: A. Prieto Cantero, "Los archivos históricos universitarios españoles, Ensayo de un esquema de organización”, Boletín de la ANABAD, XXIX, 2, pp. 221-231.

5 Basado en J.L. Rodríguez De Diego, "Archivos de poder, Archivos de la Administración, Archivos de Historia (siglos XVI-XVII)" en Generelo, J.J. Moreno López; A.(coords.), Historia de los Archivos y de la Archivística en España: Valladolid: Secretariado de Publicaciones, Universidad de Valladolid, 1998, pp. 31 y ss.; y "La formación del Archivo de Simancas en el s. XVI. Función y orden interno", en López Vidriero, $\mathrm{M}^{a}$ L. y Cátedra, P. El libro Antiguo Español IV. Coleccionismo y biblioteca. Siglos XV-XVIII. Salamanca: Universidad de Salamanca, Patrimonio Nacional, Sociedad Española de Historia del Libro, 1998, pp. 519-557. 
custodiados en los diferentes archivos universitarios. Es el caso por ejemplo de los inventarios de 1512, 1523 y 1526 para la Universidad de Alcalá, los cuatro que se realizaron desde 1569 y durante los siglos XVII y XVIII en la Universidad de Granada y los que se hicieron en la Universidad de Valladolid en 1606 y 1641 entre otros, por no mencionar los realizados en las mismas fechas en otras universidades como Zaragoza, Sevilla o Salamanca. Por primera vez se buscan respuestas concretas a problemas reales y se suscitan hipótesis que deberán ya ser tenidas en cuenta en el futuro para clasificar, ordenar y describir documentos. Los Archivos Universitarios continuaron bajo la jurisdicción del Secretario u otro personal de escriturado y custodia, sometidos al control de las autoridades gubernativas y de los diferentes llaverizos. Asimismo, los continuos Estatutos, al menos en las Universidades Mayores, obligaban a un cierto tratamiento documental que más tarde cristalizaba, a partir de los diferentes Claustros, en la formalización de desiguales instrumentos de descripción archivística. Gracias a ellos podemos desvelar, en muchos casos, parte de la documentación perdida o disgregada.

\section{2) La Archivística universitaria como desarrollo bistoriográfico}

Nos adentramos a continuación en una etapa especialmente relevante para la historia de la archivística universitaria. Debemos recordar en este sentido que es el momento en el que se establecen determinados enunciados teóricos o principios generales sobre los que se desarrollará posteriormente el complejo entramado conceptual, y que le dan a la Archivística el rango de saber científico en consolidación. Por otro lado, y en lo que a nuestro tema hace referencia, el desmantelamiento de las universidades tradicionales, la llegada del nuevo modelo liberal, o la historiografía positivista prestarán singulares sustratos técnicos a la archivística, y la emplearán como instrumento al servicio de la Historia científica. Aproximadamente, los límites cronológicos pueden quedar situados hacia el segundo tercio del s. XX, momento en que las universidades y los archivos se enfrentan a nuevas funciones y retos, causados esencialmente por la extensión de su campo de actuación a los niveles administrativos, el desarrollo tecnológico o las nuevas necesidades informativas. Veamos escuetamente, pues, las características de la etapa que ahora nos ocupa:

- La Archivística universitaria como disciplina bistoriográfica. Los diferentes planes que regularon el funcionamiento y la administración universitaria (Plan Caballero de 1807, las continuas 
reformas alternativas de reformas liberales y restauraciones absolutistas, el Plan Pidal de 1845 o, de forma resolutoria, la Ley Moyano de 1857) centralizan, secularizan y uniforman las múltiples especificidades universitarias. Con la demolición de las universidades tradicionales un número ingente de documentos cesaron de súbito en su función primaria de garantes de prueba, materialización de privilegios, protección de jurisdicciones y aval de actuaciones, lo cual había justificado el esfuerzo de numerosos órganos y juntas universitarias para mantener los documentos y archivos reservados y conservados. Asimismo, era necesario, ahora que acaba una época, confeccionar las diferentes historias de las universidades, que en algunos casos había sido representación simbólica de un pasado glorioso imperial. Igualmente, la expulsión de los jesuitas y el marco desamortizador durante las décadas centrales del s. XIX incidirán fuertemente en las universidades con recolectas multitudinarias de libros y documentos archivísticos pendientes de clasificar y consultar de forma positivista para la confección de la Historia. En definitiva, el concepto de archivo universitario adquiere una nueva dimensión, al definirse no sólo por su carácter patrimonial o administrativo - que sigue siendo fundamental—, sino sustancialmente por su finalidad histórica. En lo que a nosotros concierne, todo comienza con los intentos que tuvieron lugar en el s. XVIII para reorganizar los fondos, si bien la primera ocasión en que aparecen reflejados los archivos universitarios en un documento oficial es en el informe de Pedro Rodríguez Campomanes y José Moñino - posterior Conde de Floridablanca- allá por 1769. Más tarde los cambios acaecidos en la organización universitaria, la severa crisis sentida por la institución desde el s. XVIII, el desmantelamiento de las múltiples instituciones que habían subsistido desde épocas medievales, las pérdidas de papeles motivadas por múltiples causas (desorganización, disgregación de fondos, saqueos, guerras...) y la unificación liberal del modelo universitario, menoscabarán seriamente a la documentación ubicada en los diferentes archivos universitarios.

- Cierta formalización de la teoría y "arreglo" de los archivos universitarios. La significativa teorización que se da en el contexto global no puede ni debe quedar marginada en una periodización de la archivística universitaria. En el caso de las universidades, 
es el momento en que proliferan no sólo conjuntos de documentos incorporados venidos de diferentes instituciones y procedencias, sino también informes, memorias y documentos de juicio que tienen por objeto el 'arreglo' sistemático de los papeles y documentos generados en la cada vez más uniforme administración universitaria.

- Desarrollo de instrumentos de descripción para los archivos universitarios. La ingente documentación ubicada en las instituciones universitarias, en concierto con la disposición de la Archivística como disciplina dependiente de la investigación histórica, tienen como consecuencia directa el despliegue de la descripción documental en las universidades a través de las diversas herramientas heurísticas. El objetivo es que el historiador tenga cuantas más facilidades para su mejor investigación científica; esto es, que encuentre el dato ansiado, el documento necesitado. Es, pues el momento de los catálogos sistemáticos, de los índices y guías, de las recopilaciones documentales, de las colecciones diplomáticas. Sin embargo, no está demás recordar aquí que durante el s. XIX los archivos universitarios demandaban una urgente organización en tanto condiciones, que las autoridades seguían poniendo poco celo en la protección del patrimonio documental y que los posibles avances teóricos, por lo general, no eran reflejados en la realidad.

- Avances legislativos. Se observa de forma clara en esta época, el modo en que la historia de la archivística como disciplina, se produce un paralelismo cardinal con la acción política. Seguramente hasta la primera mitad del s. XIX los archivos universitarios permanecieron sometidos a la jurisdicción de los secretarios de las diferentes universidades. La creación, más tarde en 1856, de la Escuela Superior de Diplomática y la institución, dos años más tarde, del Cuerpo Facultativo de Archiveros, Bibliotecarios y Arqueólogos rindió importantes consecuencias en la organización de los fondos documentales universitarios. Si bien es cierto que su influencia y su verificación reglamentaria no se hicieron notar en la mayoría de las universidades hasta finales del s. XIX; sin embargo, se constata paulatinamente como factor relevante la presencia de personal profesionalizado, que aunque no con pocos altibajos, se logró atribuir a nuestras instituciones docentes. Unas veces a remolque de lo que venía sucediendo en las bibliotecas universitarias, otras con un notable 
desajuste, los archivos universitarios carecían en muy numerosas ocasiones de lo necesario para la correcta clasificación, ordenación y descripción de los fondos, que el personal intentaba solucionar con denodado empeño en lo que podían. Los archivos universitarios de Salamanca, Madrid, Barcelona y Zaragoza fueron clasificados como de tercera clase y dependientes del Fomento en presupuesto y personal. Con ello, y a pesar de los desajustes, el avance científico estaba asegurado, tanto en los instrumentos descriptivos y heurísticos que se realizaron (informes, memorias, desctripciones de fondos, adecuación a instrumentos descriptivos anteriores, etc.) como en peticiones y reclamaciones (más presupuestos, más personal, exigencias a la Junta Facultativa para que dictara instrucciones uniformes para los archivos universitarios, etc.). En definitiva, aunque con mucho esfuerzo y pocas correspondencias, los archivos universitarios fueron solventado a duras penas las dificultades.

- Incipiente desarrollo del tratamiento de la documentación administrativa universitaria. Hacia la mitad del s. XX se comienzan a vislumbrar algunas de las características que veremos consolidarse en la segunda mitad del siglo. Hacemos referencia al despliegue de la disciplina hacia los archivos administrativos, motivada en gran medida por el número ingente de documentos, el mayor desarrollo de la administración universitaria y el incremento de los mecanismos de comunicación administrativa. En el ámbito universitario, sin embargo, no siempre fue así. Algunas universidades no custodiaron de forma correcta los fondos generados tras el Plan Moyano y se limitaron a la organización, descripción y custodia de los fondos antiguos. En cualquier caso, las universidades amplían sus instalaciones -lo cual ocasiona en no pocos casos mudanzas temporales de documentos con el consiguiente riesgo-- y la administración del distrito central (Madrid) se amplía sirviendo de modelo y atracción para las restantes universidades de provincias (Barcelona, Granada, Oviedo, Salamanca, Santiago, Sevilla, Valencia, Valladolid y Zaragoza).

\section{3) La Archivística universitaria actual}

No cabe duda de que estamos ahora en un periodo donde la archivística cobra un especial desarrollo tanto en los principios conceptuales como en su aplicación práctica. Obviamente no nos detendremos aquí para explicar el vertiginoso desarrollo que ha tenido la disciplina en 
las últimas décadas y sus consecuencias directas en la documentación universitaria. Sin embargo considero que aún de forma esquemática y somera las propiedades fundamentales de la Archivística universitaria actual podrían quedar representadas en las siguientes ideas:

- Extensión del campo de actuación de la Archivística universitaria. De forma muy clara durante este período el espacio de acción de la disciplina archivística se ha expandido a la gestión administrativa. Es la respuesta a las nuevas necesidades informativas. Encontramos, pues, una considerable transformación conceptual del objeto archivístico que rebasa las inquietudes meramente históricas para llegar a una concepción global del documento.

- Expansión cientifica de la Archivística universitaria. Esto claramente percibido en el ámbito universitario, bajo nuestro criterio, por, al menos tres características: un cierto desarrollo normativo — con diferencias considerables entre unas y otras universidades - , un comedido despliegue de la política archivística universitaria a nivel estatal e incluso europeo haciendo parte de la estructura del Consejo Internacional de Archivos, y un indiscutible aumento del asociacionismo profesional, donde cobra un especial relieve la Conferencia de Archiveros de Universidades (CAU). Evidentemente todas estas reformas motivadas en gran medida en el propio desenvolvimiento de la disciplina, originan modificaciones sustanciales en los quehaceres del trabajo archivístico universitario. Ello ha supuesto que surjan nuevos temas de interés teórico y metodológico, donde la tecnología de la información, el régimen jurídico de la documentación o la normalización tienen un interés creciente en los últimos años.

- Archivos universitarios como Sistemas de Información. La expansión archivística, como decimos, se traduce ineludiblemente en una intervención global de la documentación generada, consistente en el conjunto de técnicas que se ocupa de los documentos universitarios durante su creación, mantenimiento, utilización y disposición final, y que tiene por objeto conseguir la eficiencia y la economía de los archivos mediante la simplificación de creación documental, la mejora de los sub-sistemas de clasificación, la conservación y eliminación, y la descripción y recuperación con el propósito final de conseguir una eficaz gestión de la información universitaria. 
Veamos ahora el subsistema de clasificación documental propuesto para el posterior análisis de las series documentales.

\section{Modelo de Clasificación PARA la DOCUMENTACIÓN HISTÓRICA UNIVERSITARIA.}

El modelo propuesto, como dijimos, está pensado para el momento de mayor esplendor de la Monarquía Hispánica (ss. XVI-XVIII), esto es, la época en la que se configuran las Universidades Mayores. La documentación histórica puede segmentarse en seis secciones documentales, siguiendo especialmente nuestro modelo para el Estudio Salmantino. Describámoslas someramente:

\subsection{Gobierno Y Poder}

Esta sección se reserva a las funciones directivas de la Universidad, repartidas entre autoridad pontificia, autoridad real y claustros académicos. Dejamos al margen la labor de gobierno del maestrescuela y su Audiencia Escolástica. Es sabida la constante preocupación e intervención de los poderes suprauniversitarios, monárquicos y papales en los orígenes universitarios. Por su parte, los claustros eran las reuniones periódicas, y a veces extraordinarias, de las autoridades universitarias, presididas por el rector y el maestrescuela, para el gobierno y la administración de la Universidad. La cabeza principal era el rector, que tenía derecho de convocarlos y presidirlos. El maestrescuela asistía más bien como vigilante y ejecutor de las Constituciones y ocupaba el primer lugar después del rector. Por consiguiente el claustro era el organismo capital del gobierno universitario excepto en lo relativo al fuero académico y a la colación de grados mayores, que eran funciones exclusivas del maestrescuela.

Así pues esta sección está estructurada en tres subsecciones: Autoridad Pontificia, Autoridad Real y Claustros Académicos. La primera y segunda subsecciones se corresponden con los poderes suprauniversitarios. Se reúnen aquí los reglamentos y los corpus normativos que rigen todos los aspectos de la vida universitaria. La tercera subsección se corresponde con el gobierno interno de la Universidad, representado por las autoridades del Estudio.

\subsection{Secretaría}

La segunda sección está ocupada por la función administrativa regenteada por el Secretario. No obstante, funcionalmente, aquí limitamos su actuación a la labor docente y discente; esto es, al estudio de 
la trayectoria estudiantil (matriculación, probanza de cursos, exámenes, incorporaciones, bachilleramientos, licenciamientos y doctoramientos, y visitas de pupilajes y hospedajes) y la trayectoria docente (oposición de cátedras, provisión de cátedras, visitas de cátedras, y ausencias y jubilaciones de catedráticos). Dejamos pues al margen las funciones que desempeñaba en los claustros, las hacendísticas y las de protocolo y ceremonia.

De esta manera la sección estará estructura en dos subsecciones: Alumnos, cursos y grados; y Profesores y cátedras. La primera se ocupa del dispositivo discente, es decir, de la trayectoria que sigue el universitario en los distintos niveles de la vida académica. Atenderá, pues, al recorrido que sigue el estudiante desde que llega a la Universidad y se presenta a las autoridades académicas y se inscribe en la matrícula, hasta que tras haber aprobado los cursos correspondientes y superado el grado de bachiller se licencian y doctoran, pasando por los pupilajes, hospedajes y domicilios. La segunda, por su parte, se emplea en la labor docente, en donde las cátedras ocupan un lugar central y se convierten en el símbolo de la transmisión del saber.

\subsection{Hacienda}

La tercera sección de nuestra propuesta está ocupada por la función hacendística. Recogerá todo lo relativo a los ingresos, gastos y balances; esto es, al funcionamiento económico-presupuestario de la institución universitaria. La hacienda universitaria nos muestra una organización estructurada en unos órganos colectivos de decisión, que son los claustros y las juntas. Además, existen unos ministros u oficios con funciones delegadas, que dependen de la Universidad, y que pueden corresponderse con el Mayordomo, el Administrador y el Síndico. Y, por último, en determinadas instituciones universitarias, como Salamanca, al margen del arca principal, encontramos otras paralelas y vinculadas: el arca de Primicerio y el arca del Colegio Trilingüe.

De esta manera la sección estará estructura en cuatro subsecciones: Juntas, oficios y balances; Ingresos y tercias; Gastos; y Cuentas particulares. La primera subsección ocupará el balance de las contabilidades de la Universidad, basándose en las series documentales más importantes procedentes de los órganos de decisión, juntas y oficios. La segunda estudiará los múltiples ingresos o cargos de la hacienda universitaria; también nos fijaremos en los censos, los derechos del arca de grados y las multas de cátedras. La tercera subsección se ocupará de los gastos o descargos de la hacienda: salarios 
y censos, obras y reparaciones y actos académicos. Al margen contamos con una cuarta subsección dedicada a las cuentas o haciendas particulares y vinculadas a la Universidad.

\subsection{Protocolo y Ceremonia}

La cuarta sección está ocupada por la función protocolaria y ceremonial de la Universidad. Quedan aquí inmersos los usos y costumbres formales y rituales académicos y el protocolo tradicional preocupado por la pompa y los festejos universitarios. Por consiguiente tienen cabida en esta sección tanto las fiestas académicas como las fiestas religiosas en el marco universitario. De todo ello será fedatario el Secretario, quien se encargará de registrar todos los actos protocolarios.

De esta manera la sección estará estructura en cuatro subsecciones: Capilla de Música; Capilla de la Universidad; Fiestas de Primicerio; y Fiestas universitarias. La primera subsección demuestra la preocupación por la pompa y los festejos académicos; la segunda se destina a uno de los lugares de mayor raigambre universitaria. Los grados universitarios, las fiestas y honras, las visitas, los oficiales propios, capellán y sacristán, o los continuos gastos suntuarios que ocasionaban los actos allí realizados, son prueba de ello. De esta forma la capilla se convierte en uno de los testigos de la actividad académica, docente y festiva. La tercera subsección se ocupaba de organizar los festejos y solemnidades académicas, tales como procesiones y actos de Capilla, honras y entierros, corridas de toros, etc. Con toda magnificencia celebraba la Universidad las festividades de los santos principales. En la cuarta se constatan con Libros de Informaciones y Cuentas, las fiestas universitarias. Suele reunir documentación de diverso tipo que ha sido consignada por el Secretario: visitas ilustres, comedias representadas en "días de regocijo", cuentas y recibos de gastos por razón de fiestas y solemnidades, recibimientos y honras fúnebres a personas reales, colaciones y comidas, fiestas de toros, trajes festivos, etcétera.

\subsection{Maestrescuela, Audiencia Escolástica y Pleitos}

La quinta sección está reservada a la función del maestrescuela y su Audiencia Escolástica. Era éste el representante simbólico del poder pontificio, y administraba la autoridad apostólica de colación de grados, admitiendo o negando la aprobación de bachilleres, licenciados y doctores, así como las incorporaciones de estudios de otras Universidades. Le correspondía, asimismo, hacer valer y respetar las Constituciones y Estatutos universitarios, y compeler al rector 
y restantes oficios del gremio al cumplimiento de los deberes de su cargo. Asistía a las juntas, claustros y actos académicos, en los que ocupaba el primer lugar después del rector, precediendo a éste en las ceremonias de los grados. Su atribución más importante residía en ejercer jurisdicción civil y criminal sobre el Estudio, con poder de amonestar, excomulgar, penar y castigar de diversas formas y maneras. Esta supervisión de las costumbres le confería poderes para desterrar a cualquier escolar dañoso para la moralidad general; podía otorgar o negar licencias de bachilleres de pupilos y visitar anualmente los pupilajes de éstos. Además el oficio se completaba con otras prerrogativas, como la de ser uno de los claveros del arca universitaria y guarda del sello de la corporación o gremio estudiantil. $^{6}$

De esta manera, la sección estará estructura en tres subsecciones siguiendo el modelo salmantino: Maestrescuela y Audiencia Escolástica; Tribunal del Administrador; y Otros pleitos. En la primera subsección se refleja cómo la jurisdicción la ejercía el maestrescuela por medio de su Audiencia o Tribunal Escolástico, para el que nombraba juez, fiscal, procurador, notarios y alguacil, disponiendo además de cárcel propia. La segunda subsección, expone la función del administrador de administrar los bienes y rentas del Estudio. Con el correr del tiempo, acentuará sus características de Juez Apostólico-Administrador, poseyendo tribunal y poder de censuras, y dilucidando los pleitos de rentas. La tercera subsección abarca aparte de los pleitos del maestrescuela con su Audiencia Escolástica y de los del Juez de Rentas a través del Tribunal del Administrador y otros pleitos en el ámbito jurisdiccional de la Universidad, fruto de su complejidad orgánica e institucional, que desarrollará otras series documentales.

\subsection{Instituciones Vinculadas}

Por último la sexta sección está reservada a las funciones que desempeñan las instituciones vinculadas en el marco general de la institución universitaria. No olvidemos que las Universidades $\mathrm{Ma}$ yores, especialmente Salamanca en su etapa más clásica, se comportaron como instituciones de instituciones. Éste, y no otro, es el sentido de incorporar a nuestra propuesta los colegios, conventos

6 Vid. L.E. Rodríguez-San Pedro Bezares, "El maestrescuela y su jurisdicción” en La Universidad salmantina del Barroco... Op. Cit., pp. 381-401; y Alonso Romero, Mª. P., Universidad y sociedad corporativa. Historia del privilegio jurisdiccional del Estudio salmantino, Madrid: Tecnos, 1997. 
y otras instituciones vinculadas. De otra forma reduciríamos en gran medida lo que de hecho fue la institución universitaria. Hemos de advertir que archivísticamente se trata de fondos distintos al estrictamente administrativo universitario, que deben ser regidos por el principio de procedencia. Así, la sección, dependiendo de la Universidad correspondiente, incluiría: Colegios Mayores, Colegios Menores, Colegios Militares y Colegios y conventos religiosos.

Los Colegios Mayores, siguiendo a Carabias Torres, podríamos definirlos como

centros docentes en régimen de internado, que se caracteriza por la importancia de los privilegios de que goza, por estar acogido a la protección real y por requerir específicas condiciones físicas (edad, salud), intelectuales (ser bachiller al menos en una de las facultades mayores), económicas (pobreza), morales (vida intachable, limpieza de sangre) y determinada procedencia regional de sus miembros. ${ }^{7}$

Así pues, estas instituciones nacieron como consecuencia del esfuerzo de individuos particulares - fundadores- que pretendían ofrecer la posibilidad de una formación universitaria a algunos estudiantes valiosos, pero que carecían de medios económicos para poder emprenderla con sus propios recursos. Los Colegios Menores son fundados sobre las mismas bases que los Mayores y no se observan diferencias constitucionales que justifiquen la distinta denominación. Siguiendo a Carabias Torres, varias son las diferencias entre un colegio menor y uno mayor: la menor importancia de los privilegios reales y pontificios que poseen, la no reserva de sus becas a los estudiantes que poseyeran ya el grado de bachiller, no ser minuciosos en las informaciones de limpieza de sangre de los aspirantes a una beca colegial, no adquirir tanto valor el hecho de haber sido colegial en relación a los cargos que requieren la limpieza de sangre y no estar acogidos a la protección real. ${ }^{8}$ Los Colegios Militares por su parte, se consideraban colegios religiosos. Por tanto, tendrán las características de estos últimos, respondiendo así a las peculiaridades y Constituciones de las diversas comunidades que las constituían. Por último, los Colegios Religiosos eran múltiples y variados. Al igual que los militares, respondían a los distintivos de las diversas comunidades religiosas que los formalizaban. ca durante el siglo XVI. Salamanca, 1986, Vol. II, p. 369.

8 A. Ma.Carabias Torres, El Colegio Mayor de Cuenca en el siglo XVI: Estudio institucional. Salamanca: Univversidad, 1986, pp. 25 -27. 
3. ANÁlisis de las Series documentales para la inVESTigación EN HISTORIA DE LAS UNIVERSIDADES: EL EJEMPLO DEL FONDO HISTÓRICO DEL ARCHIVO UNIVERSITARIO DE SALAMANCA

$$
\text { (páginas siguientes) }
$$




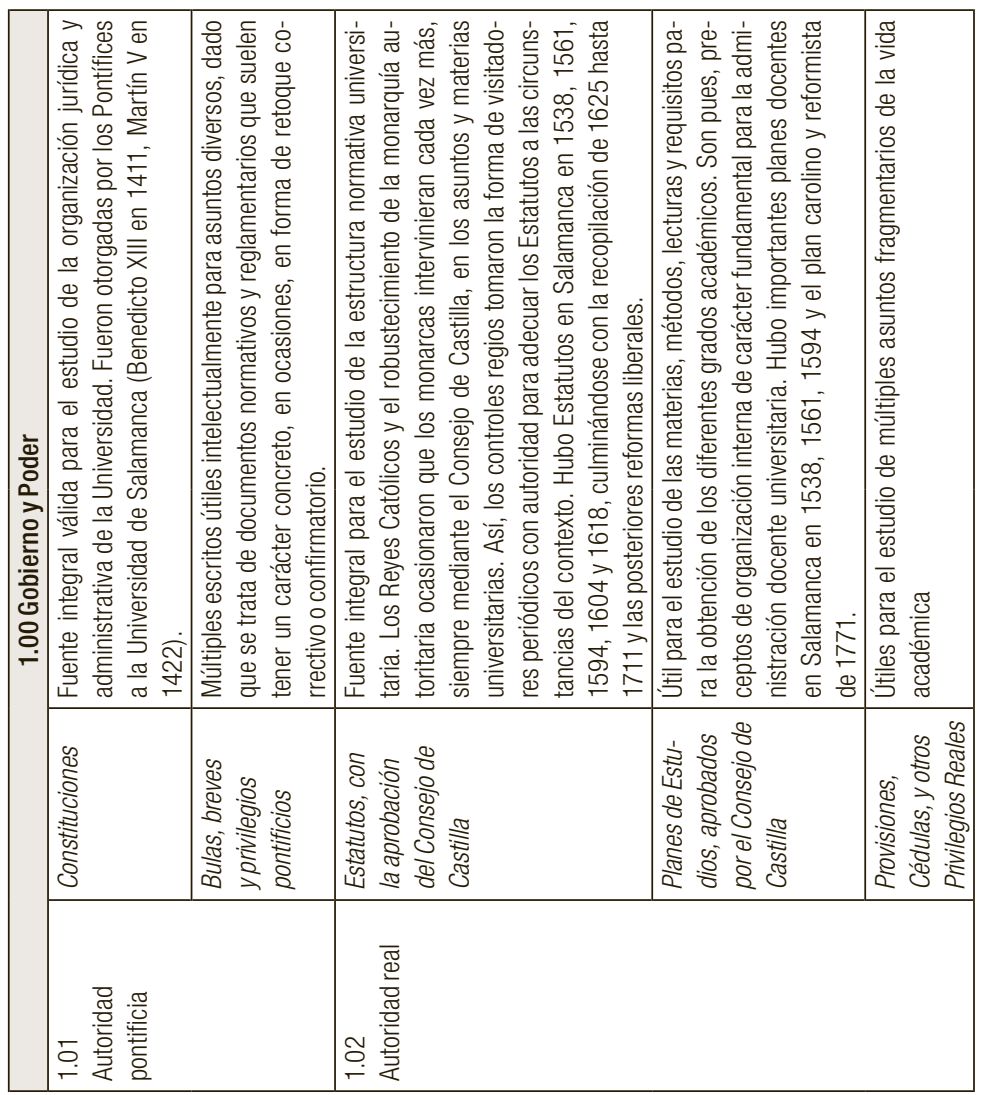




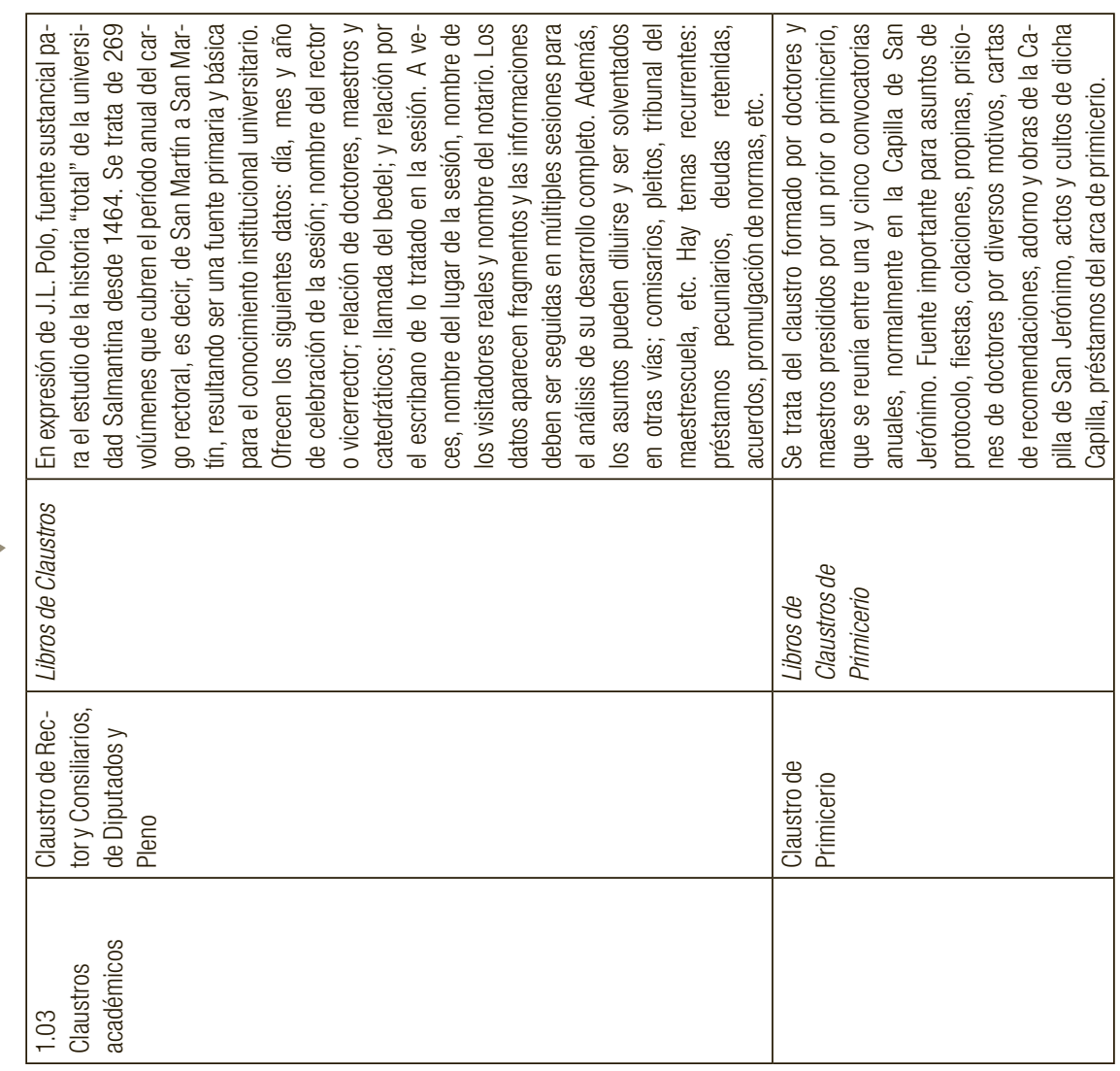




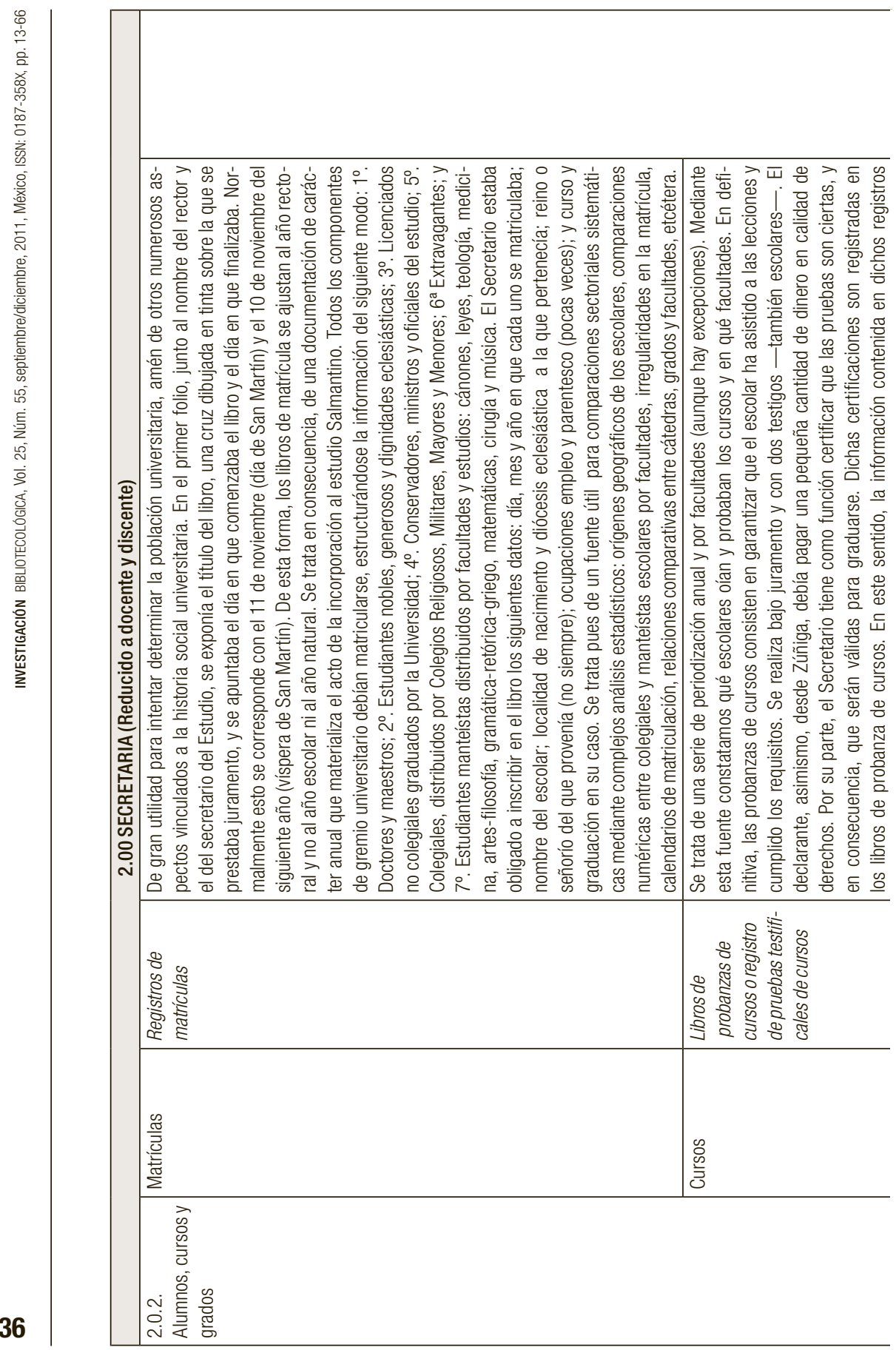




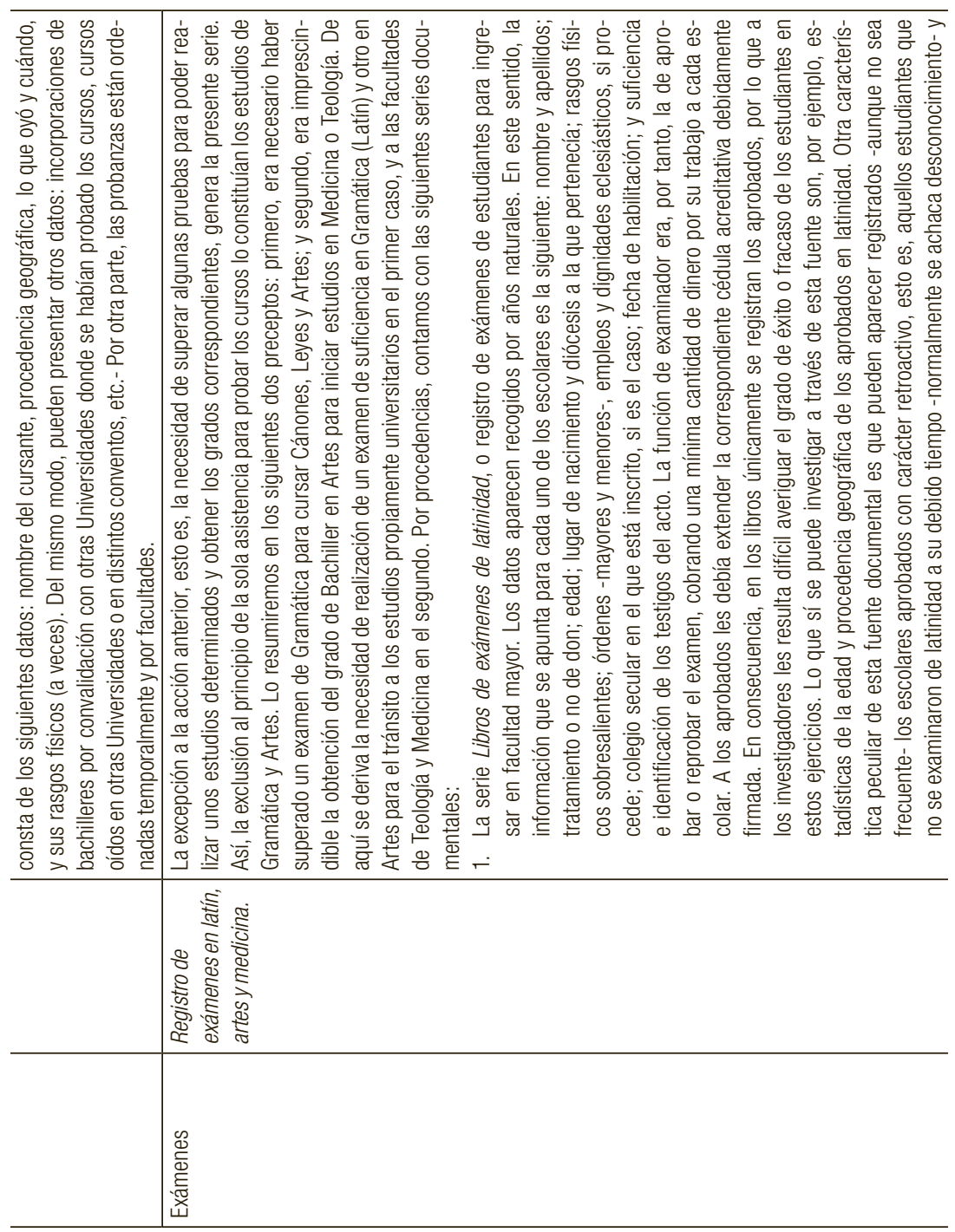




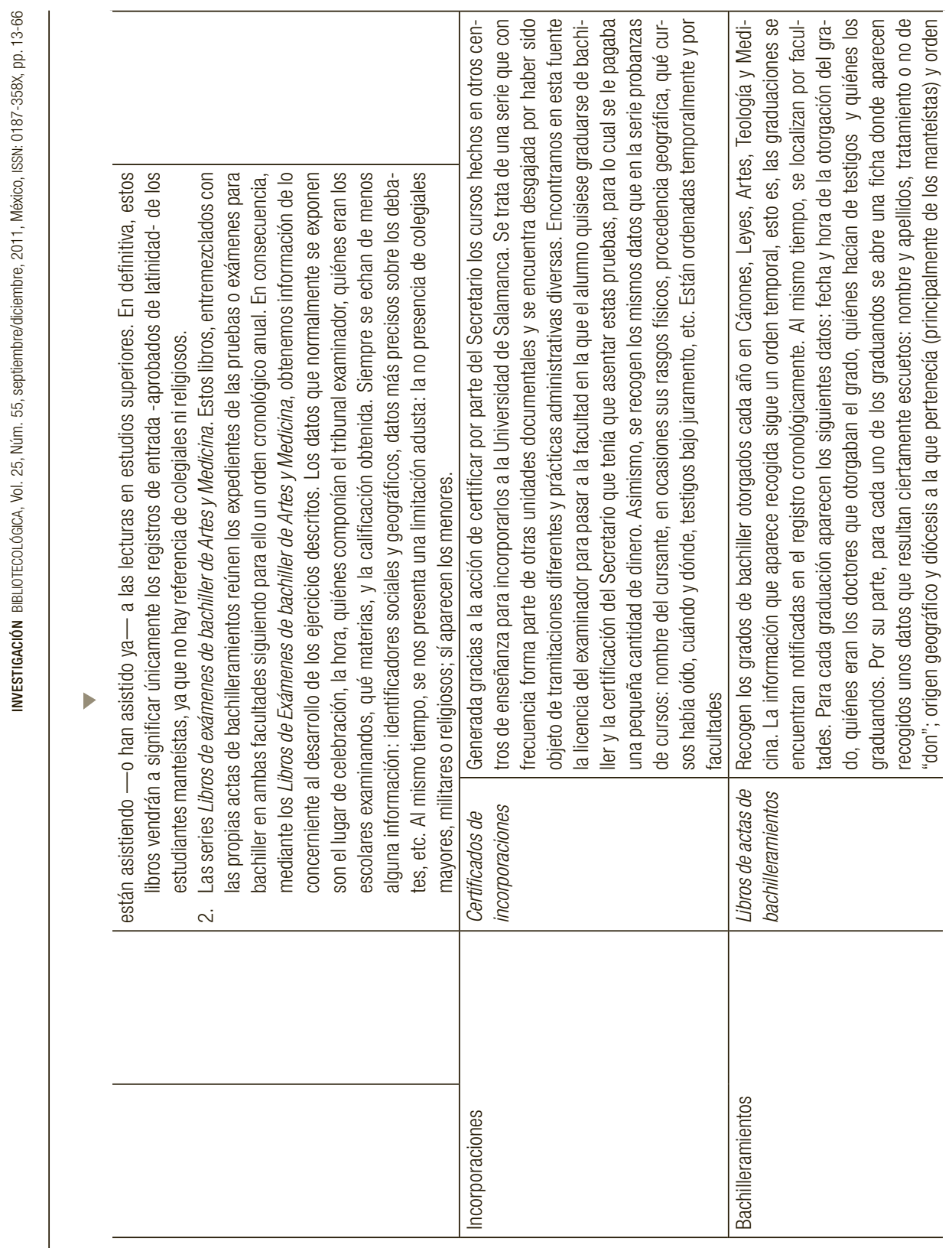




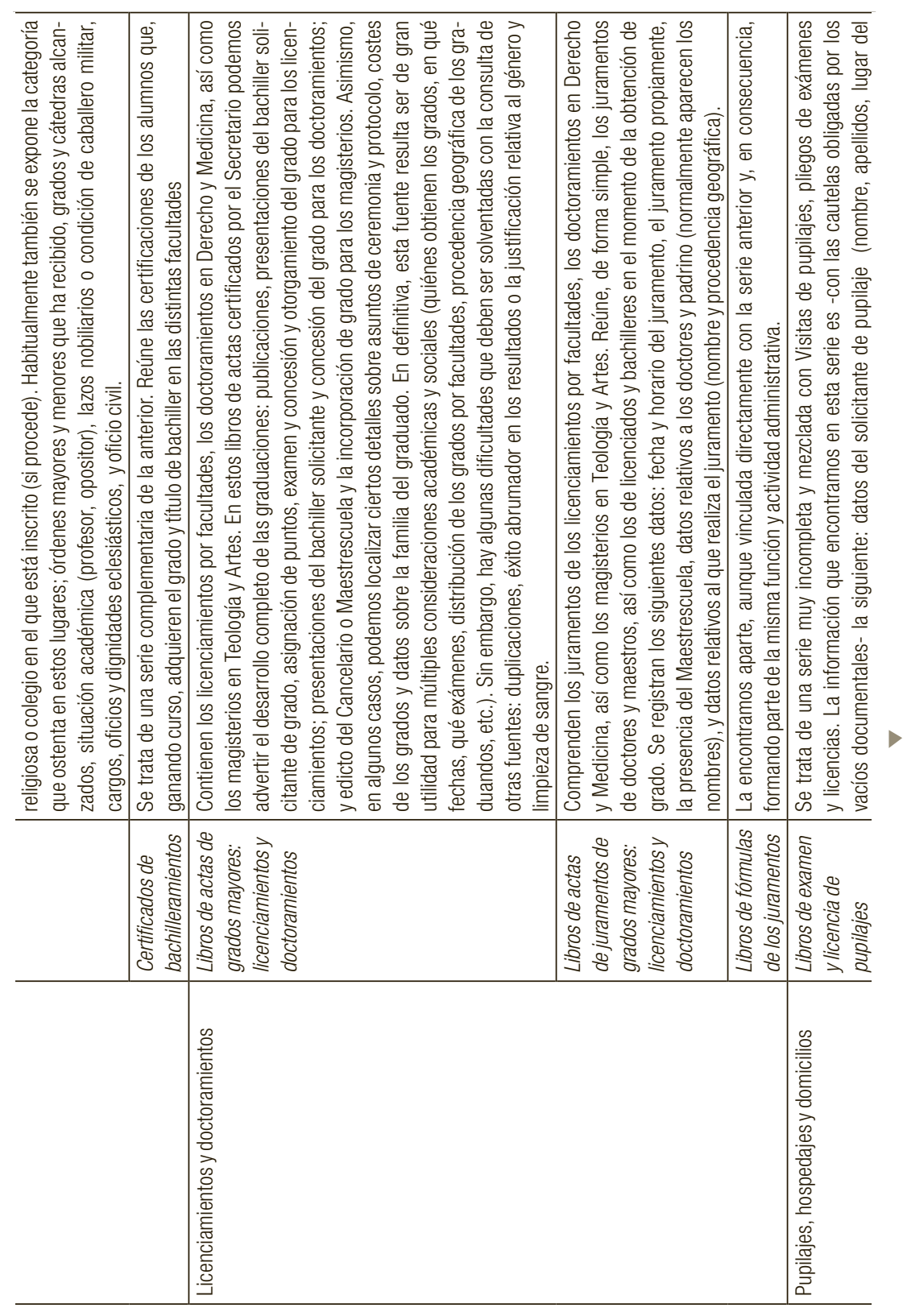




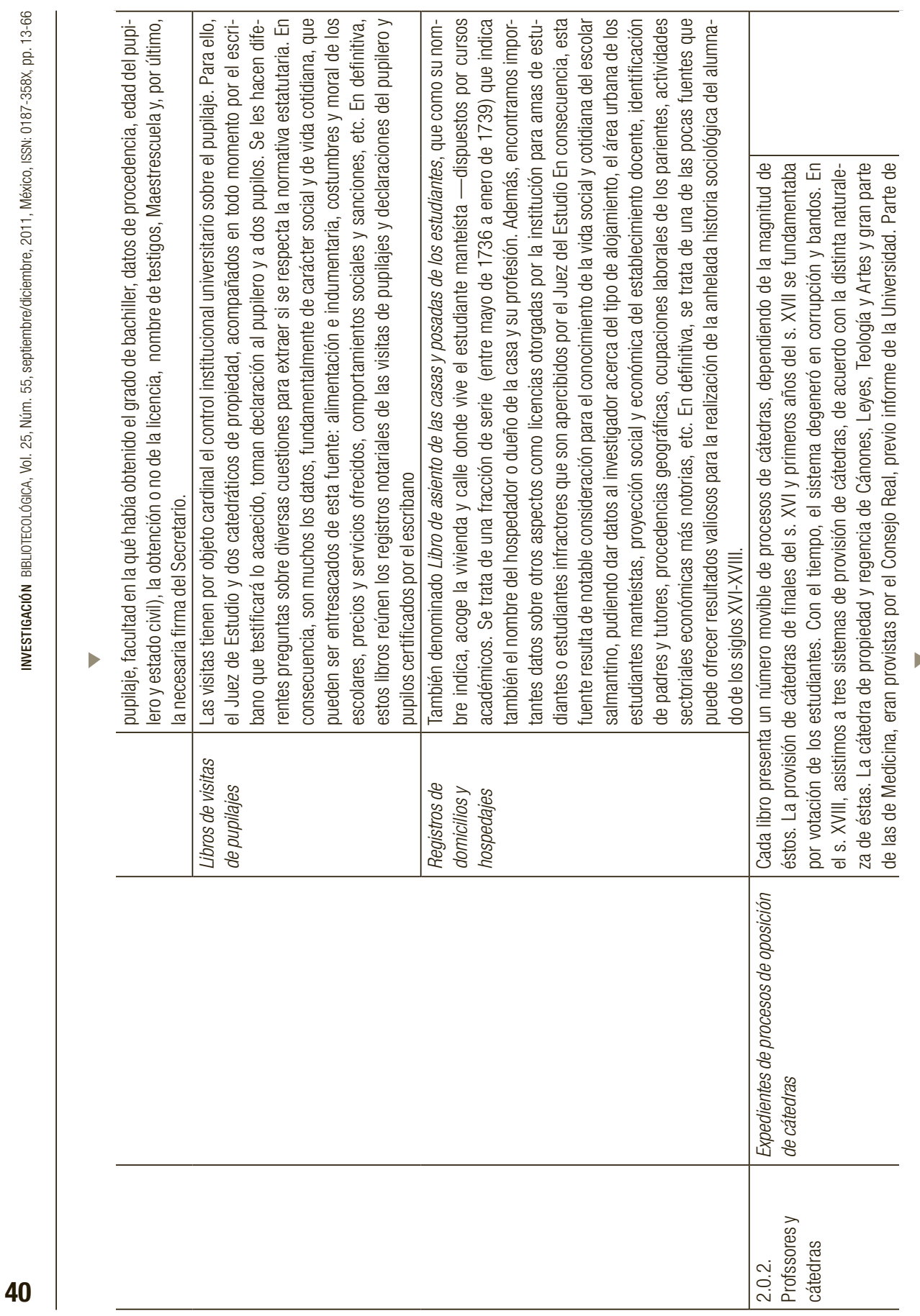




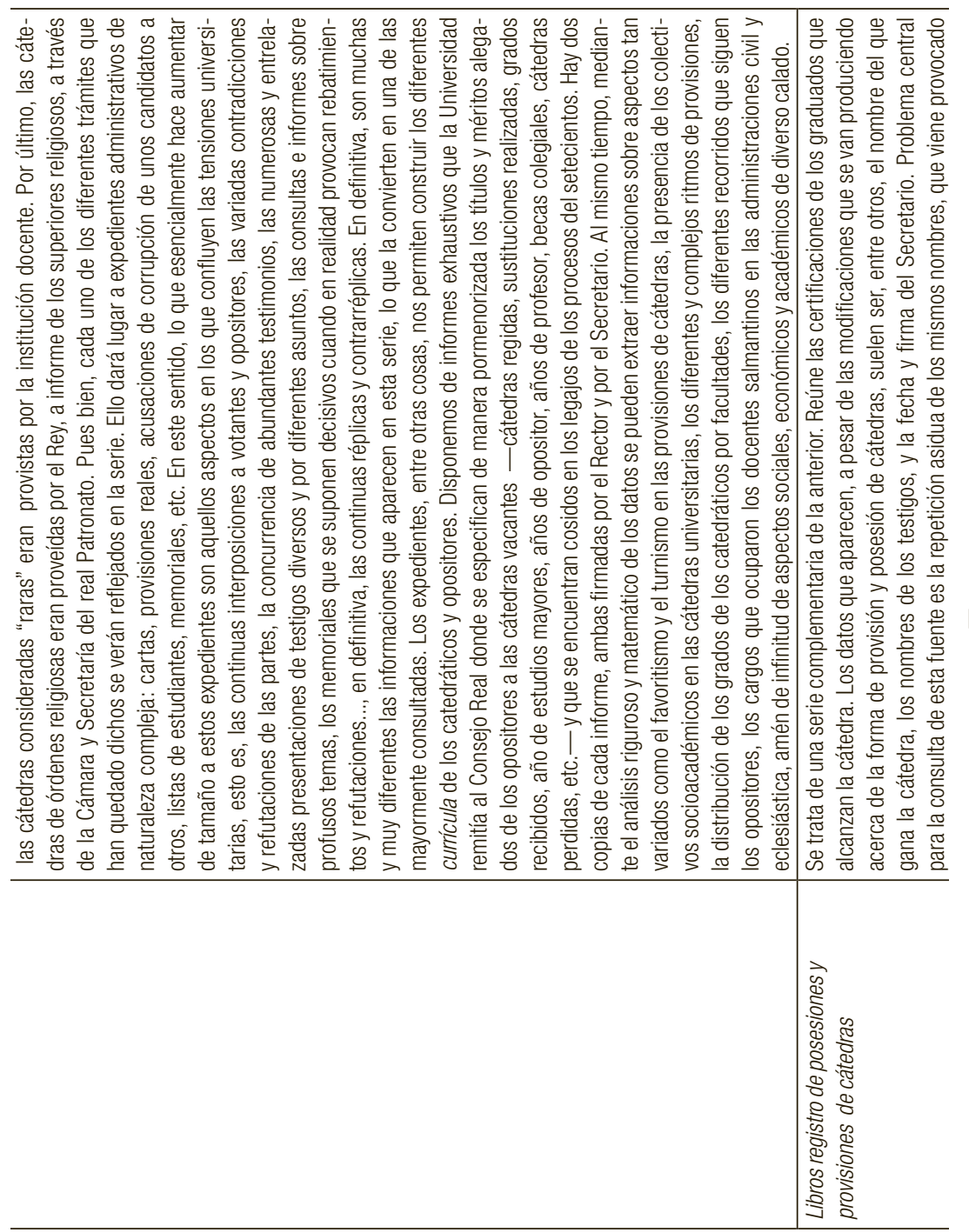




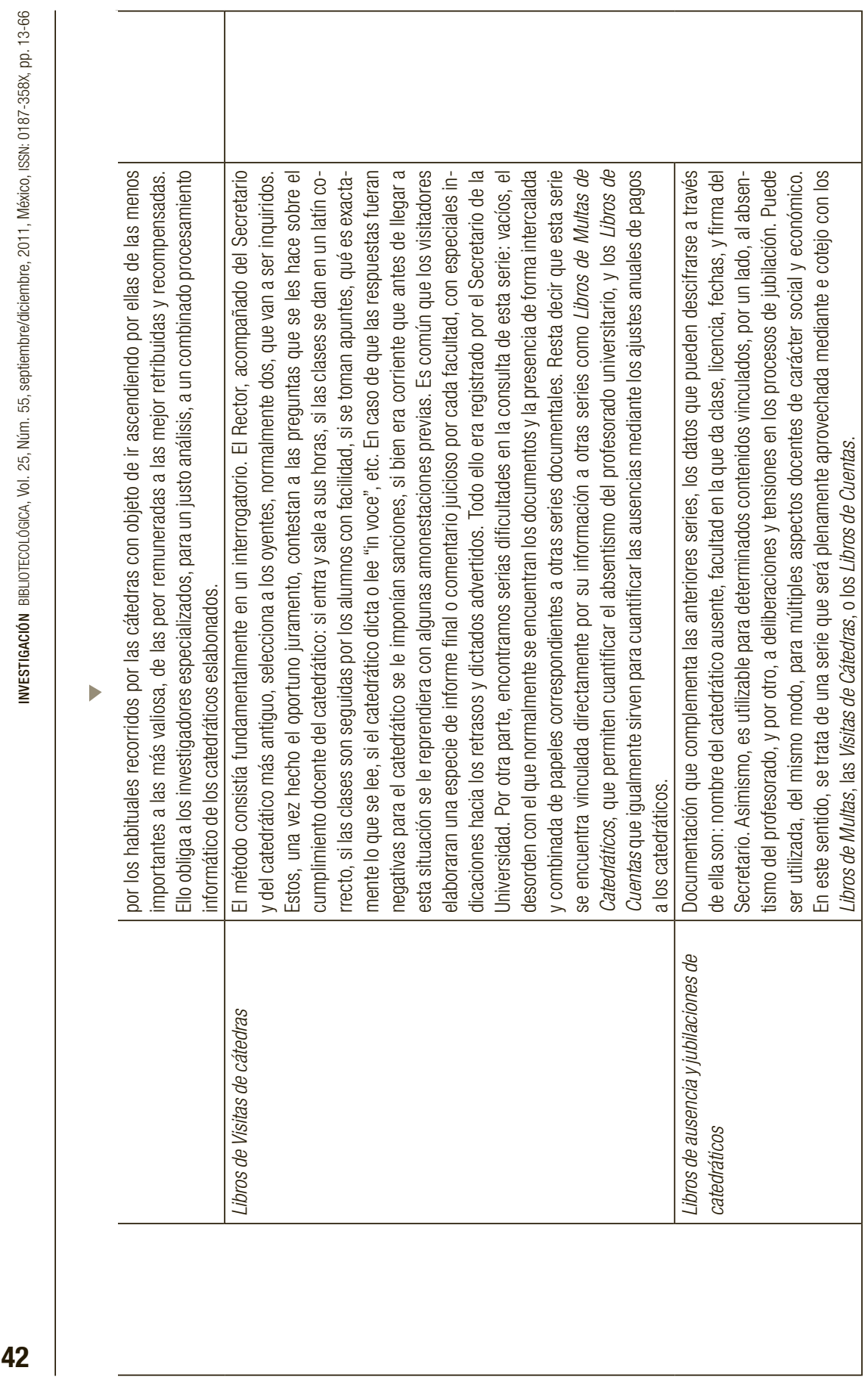




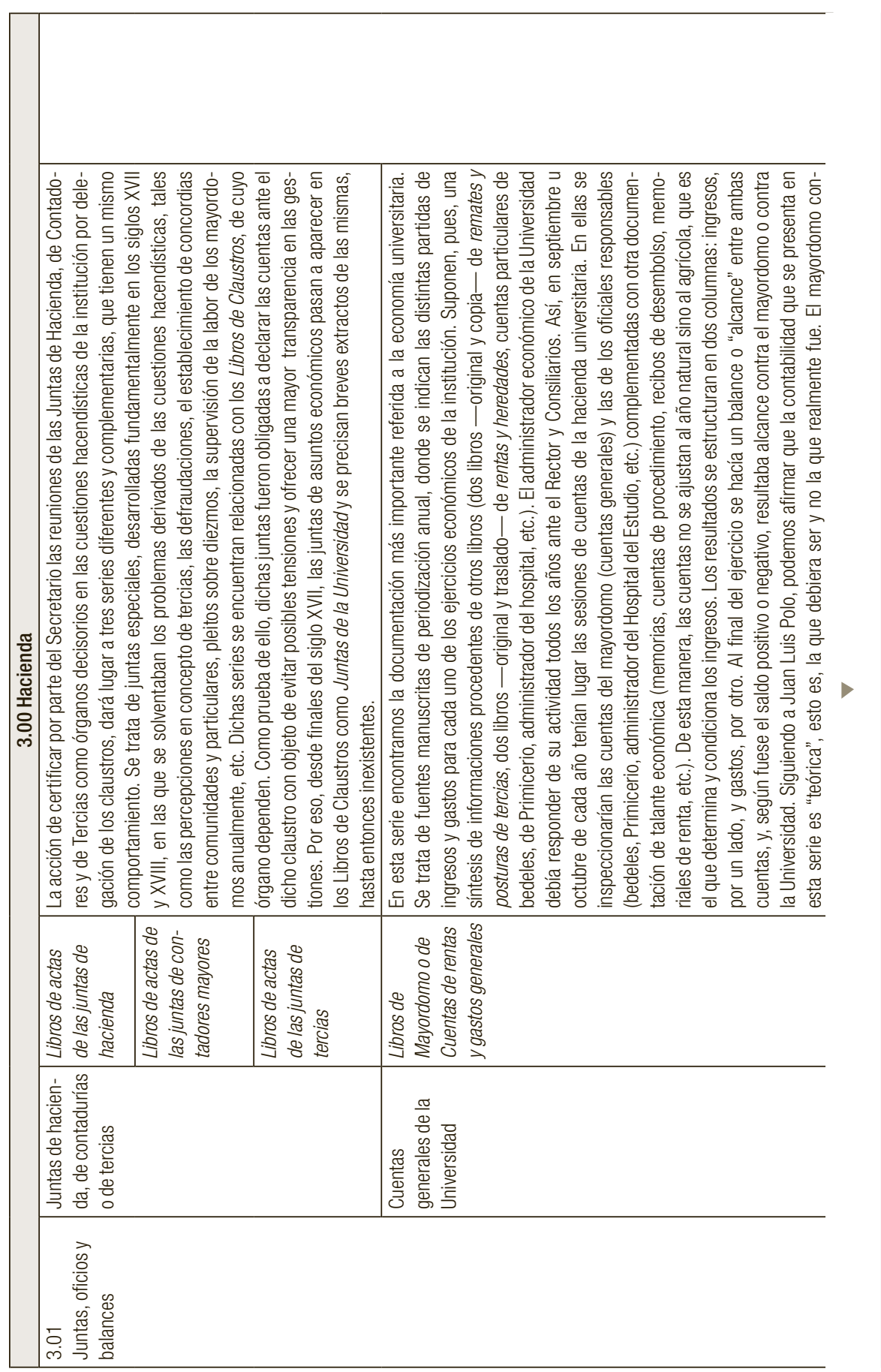




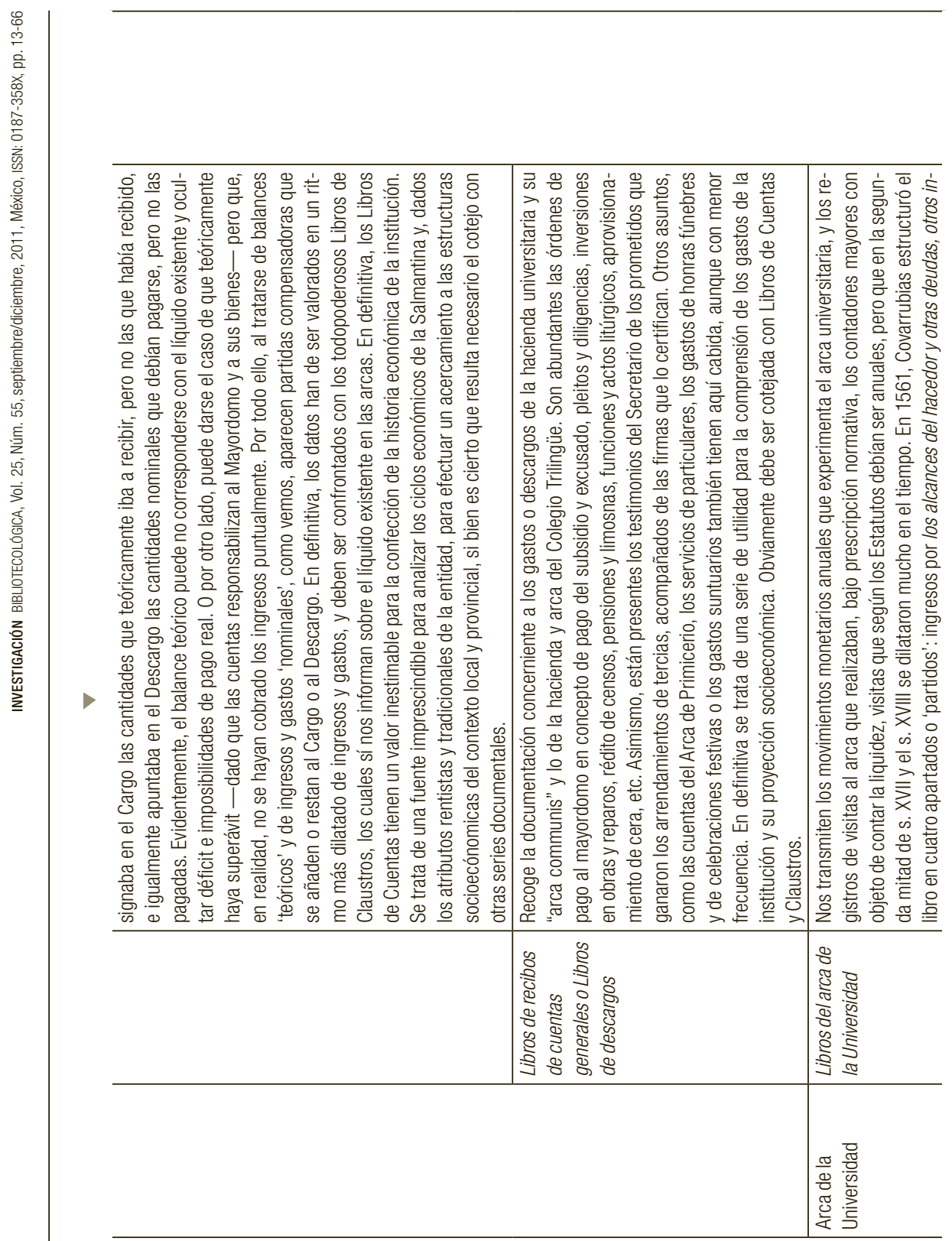




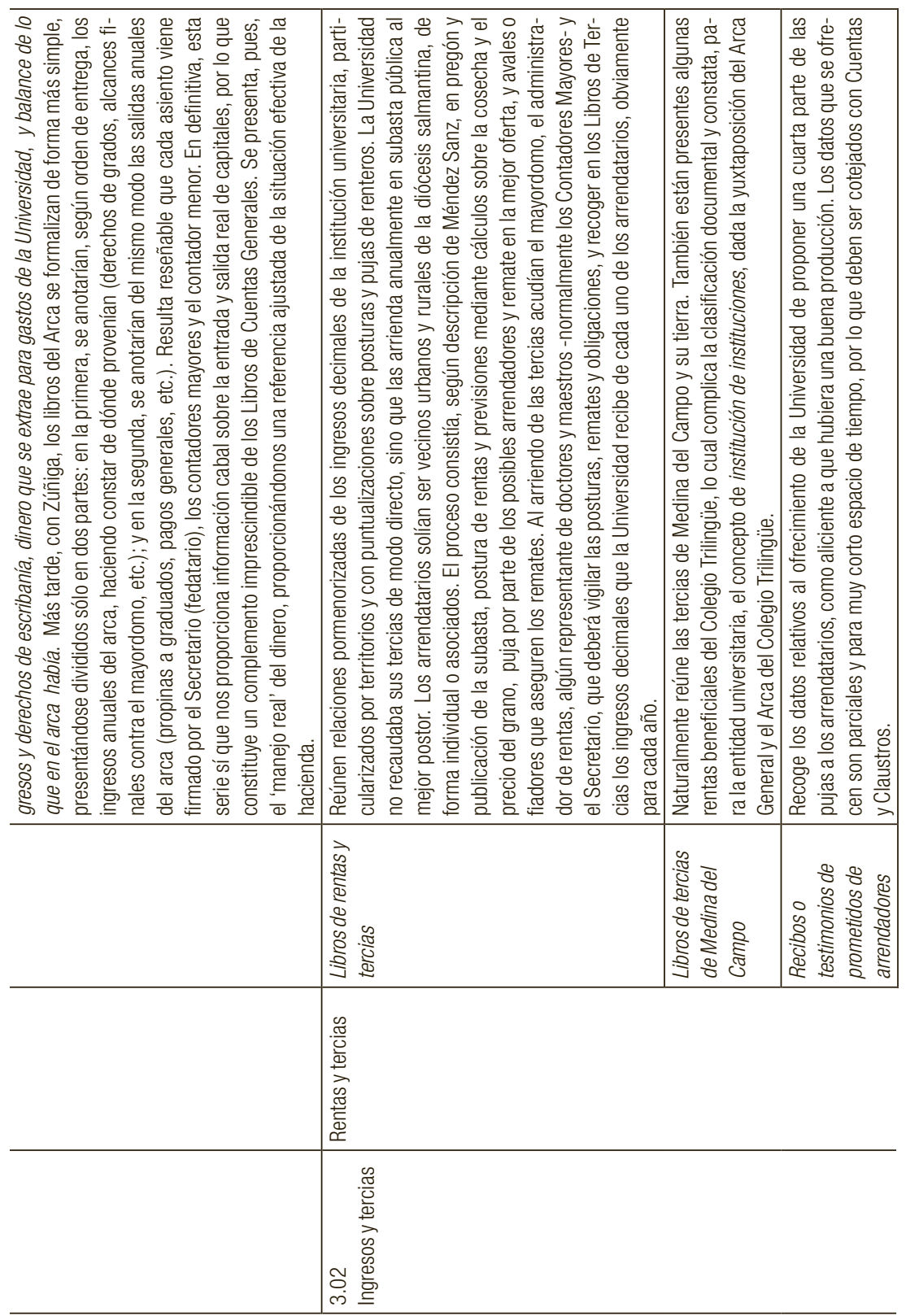




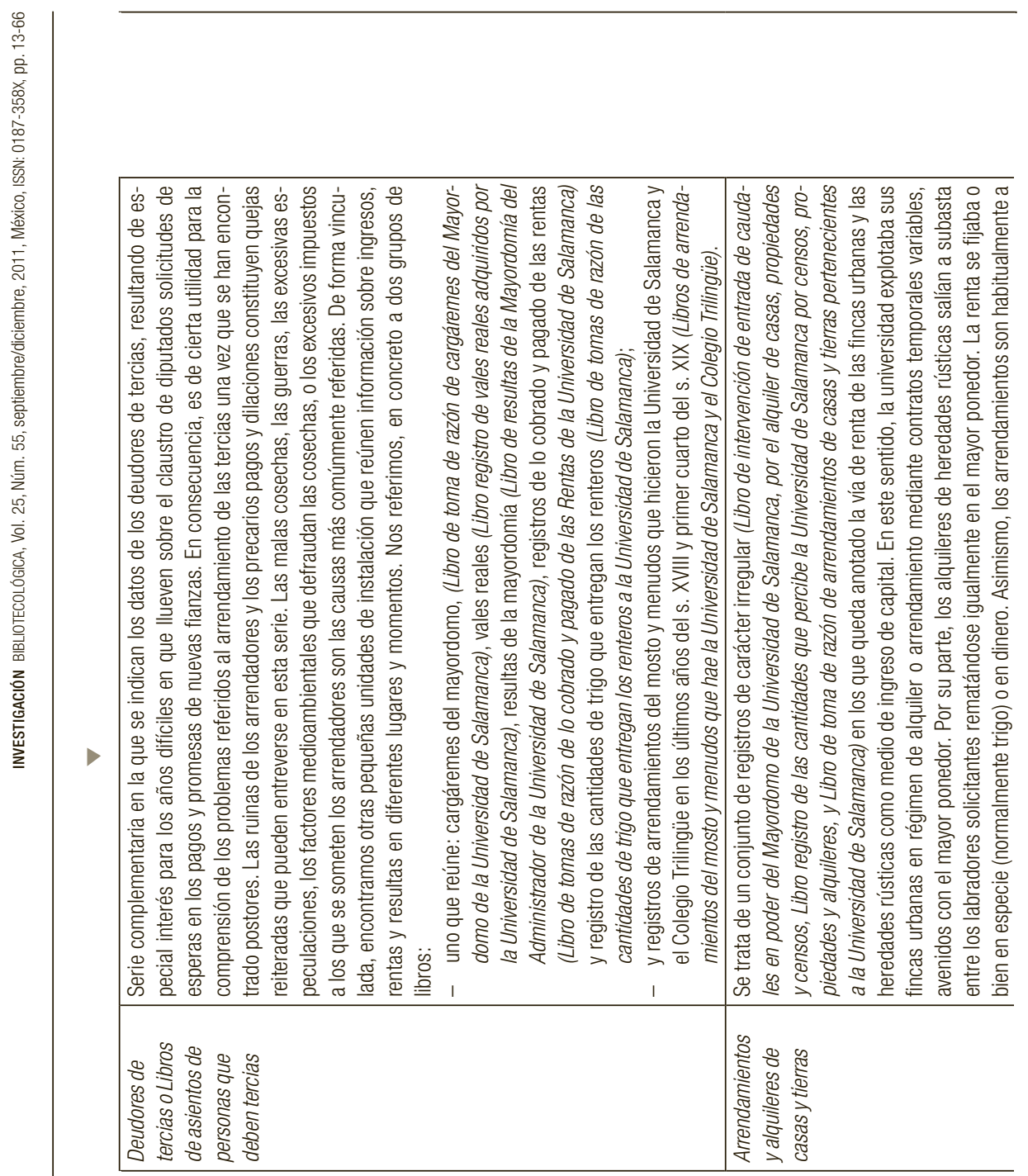




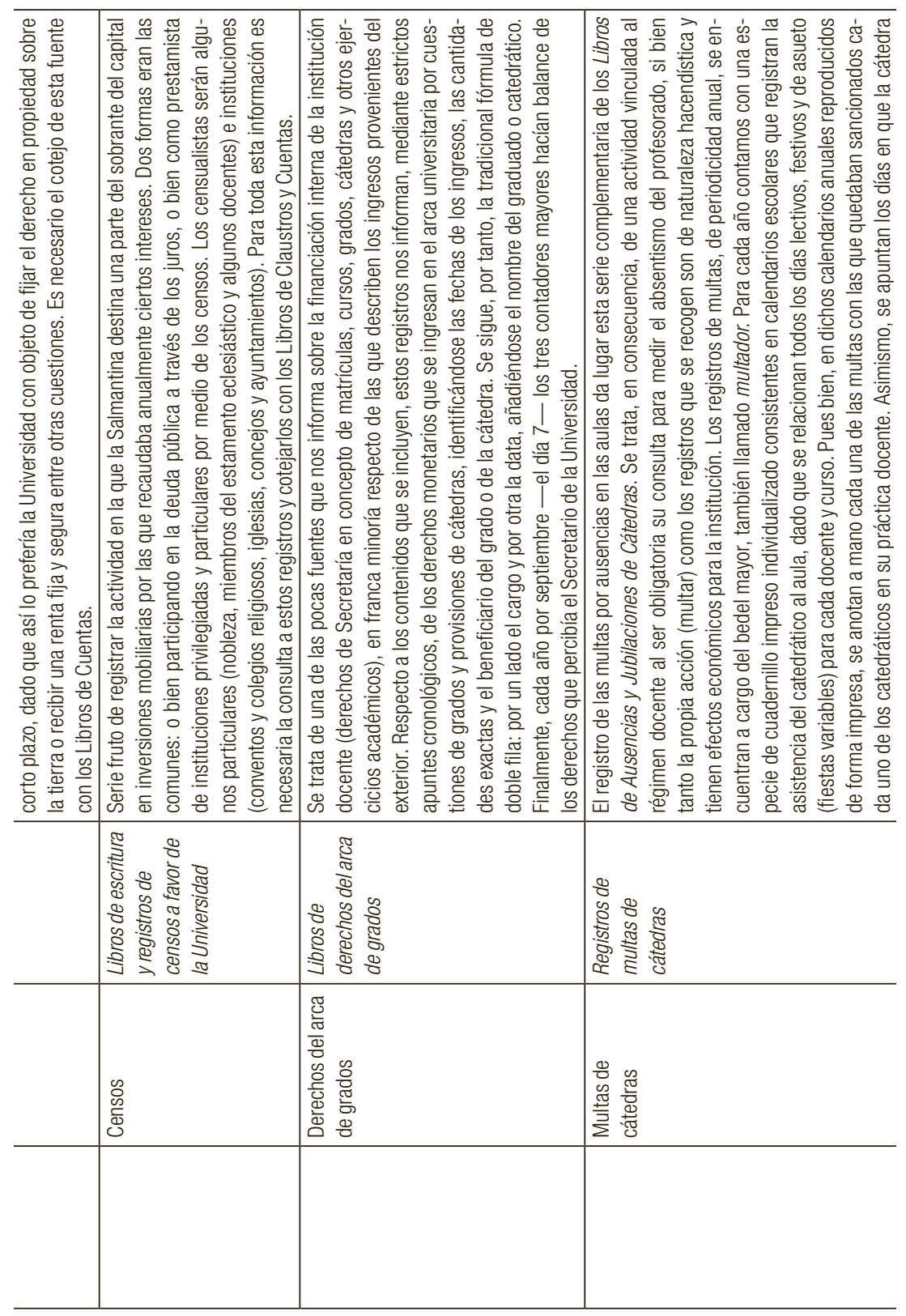




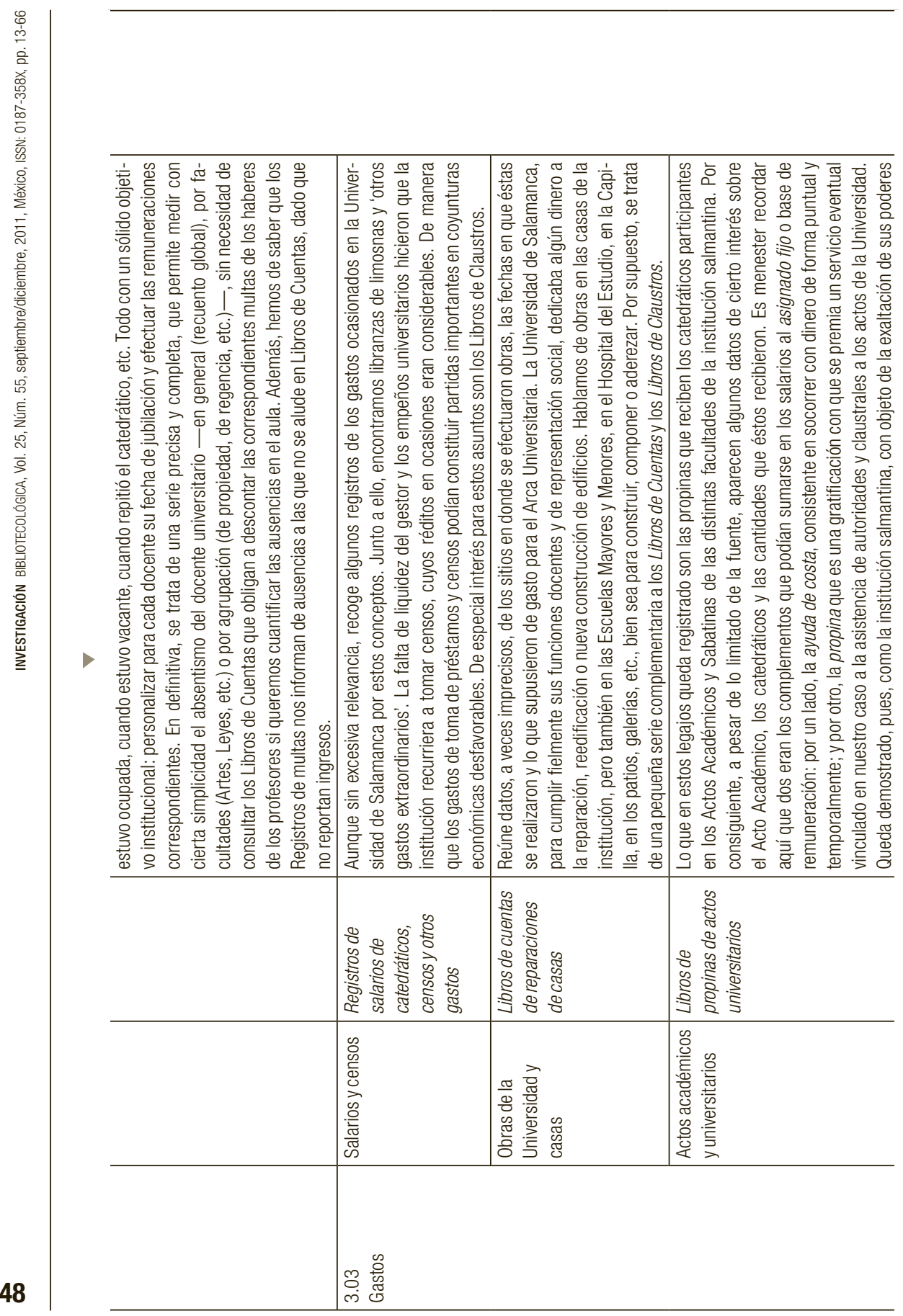




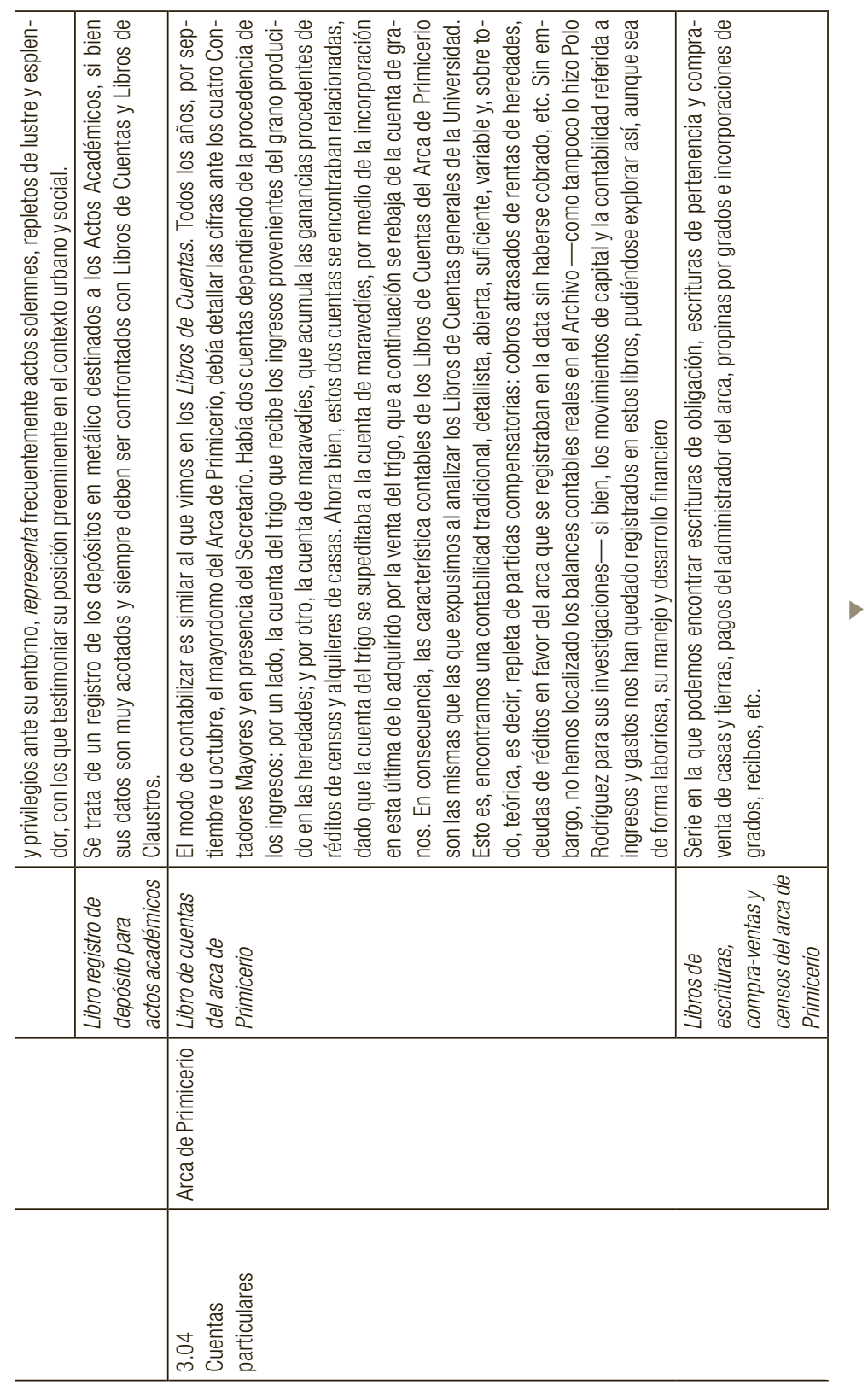



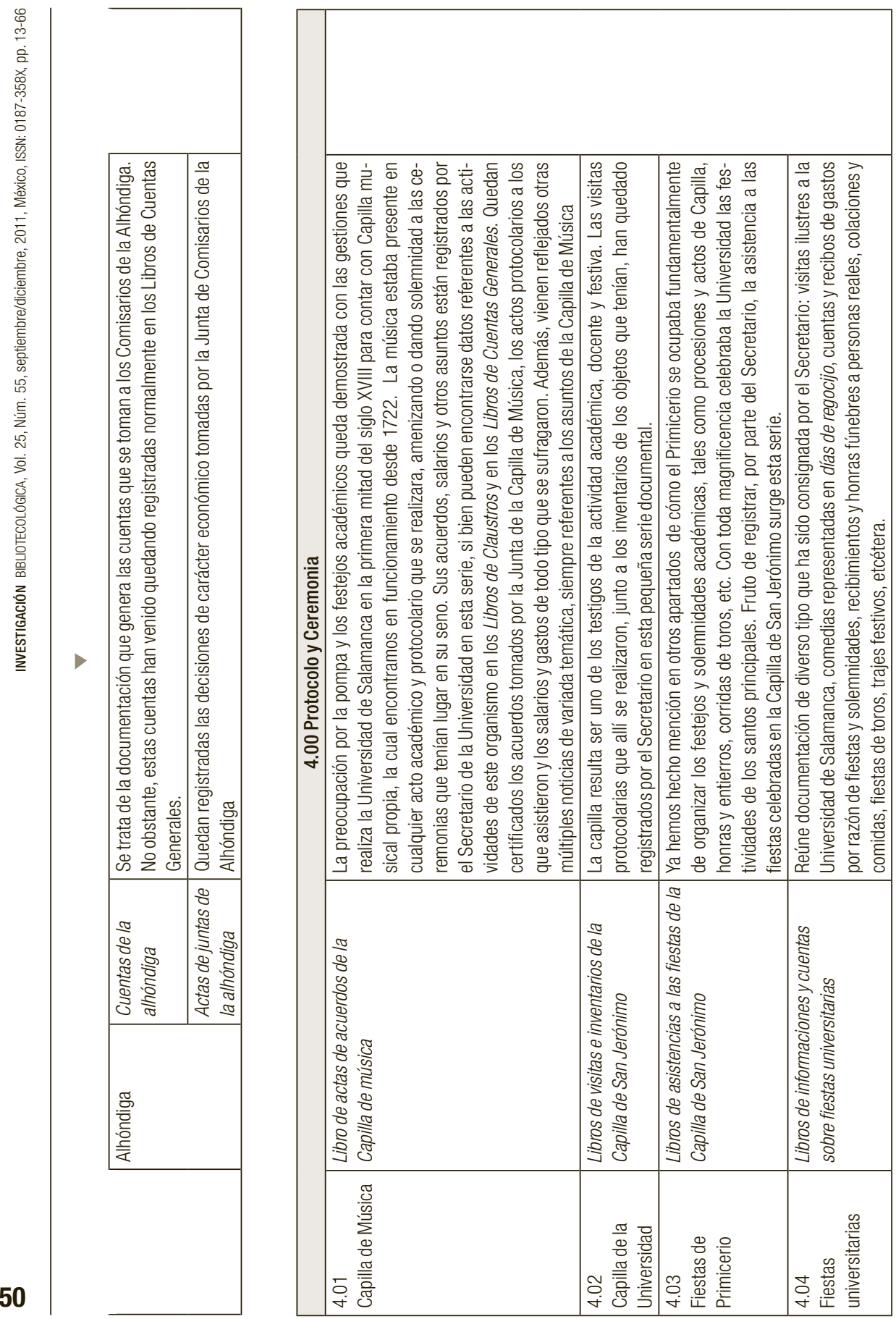


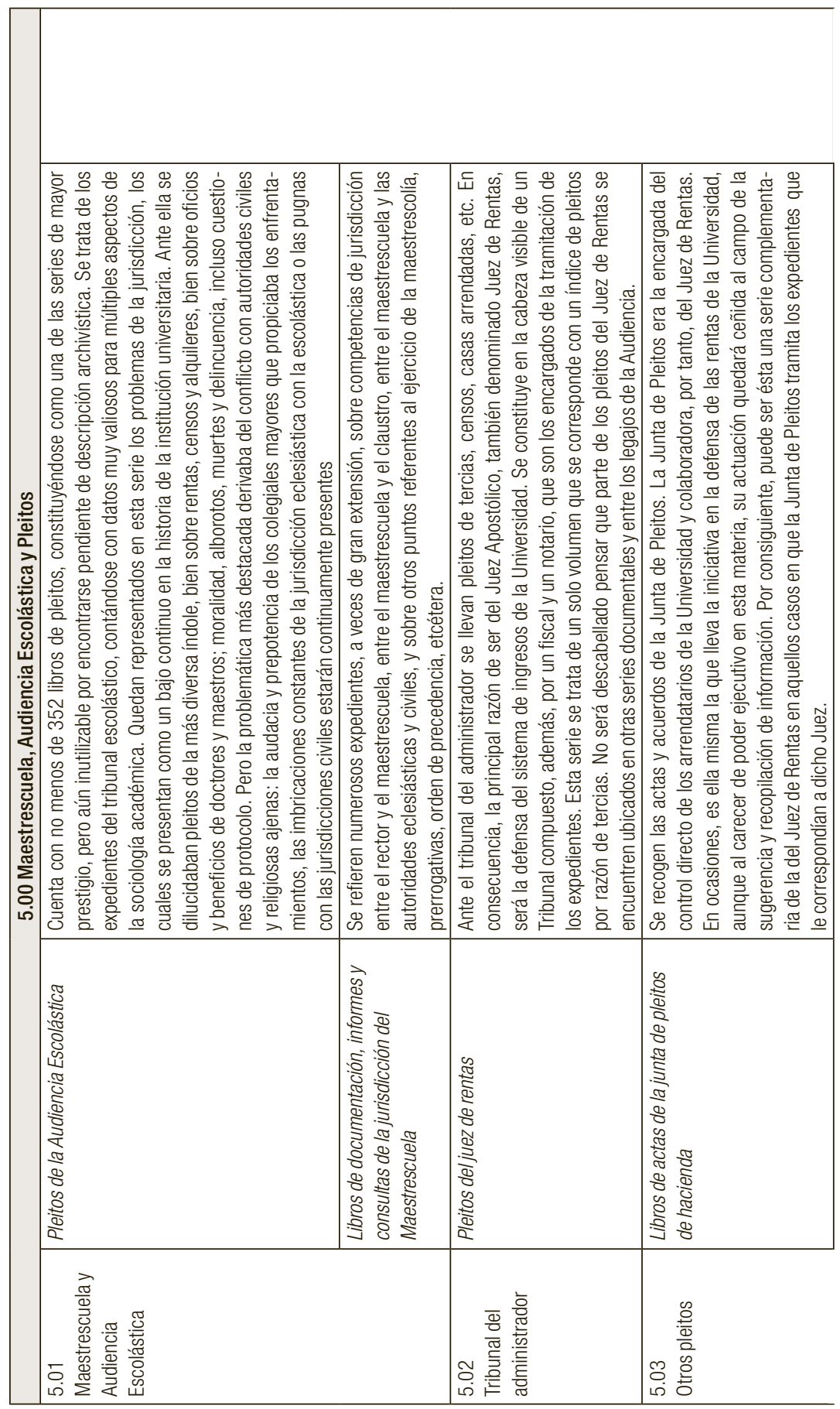




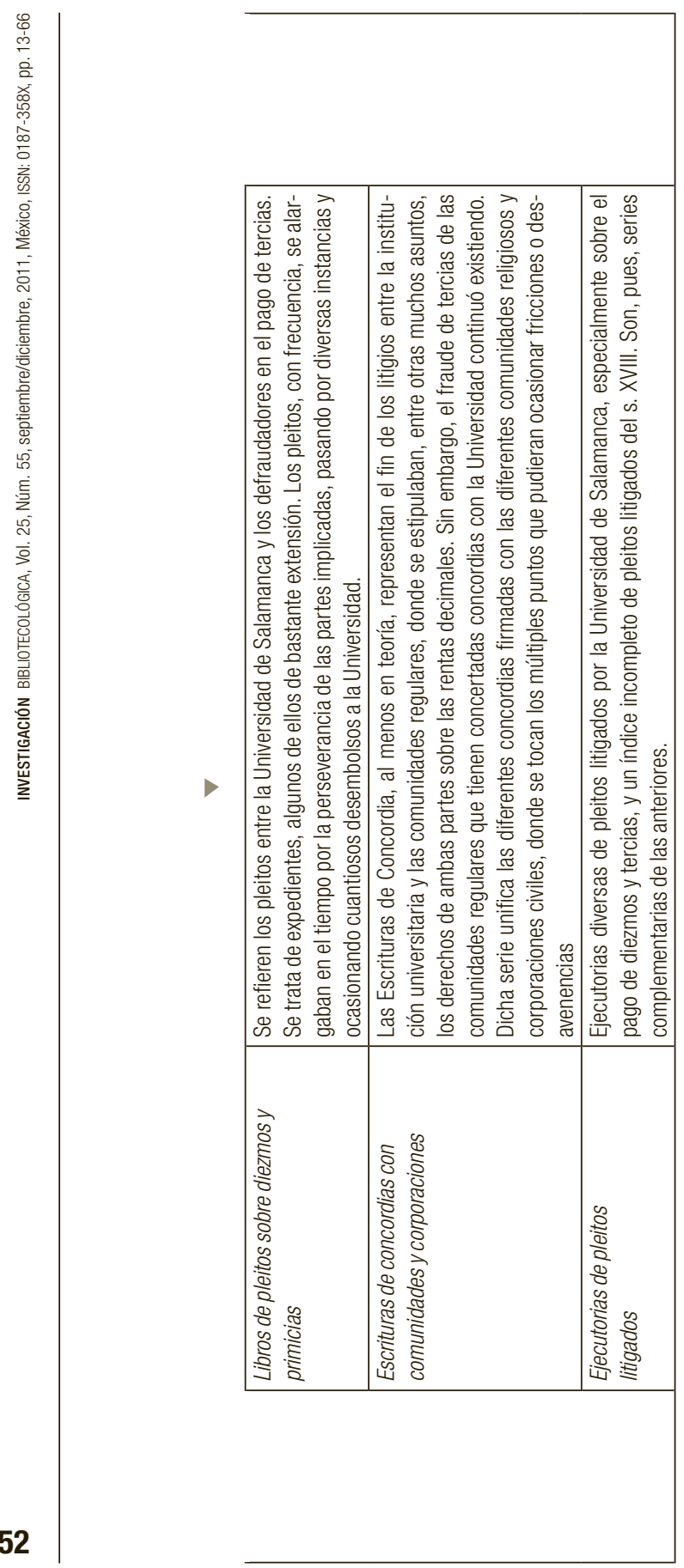




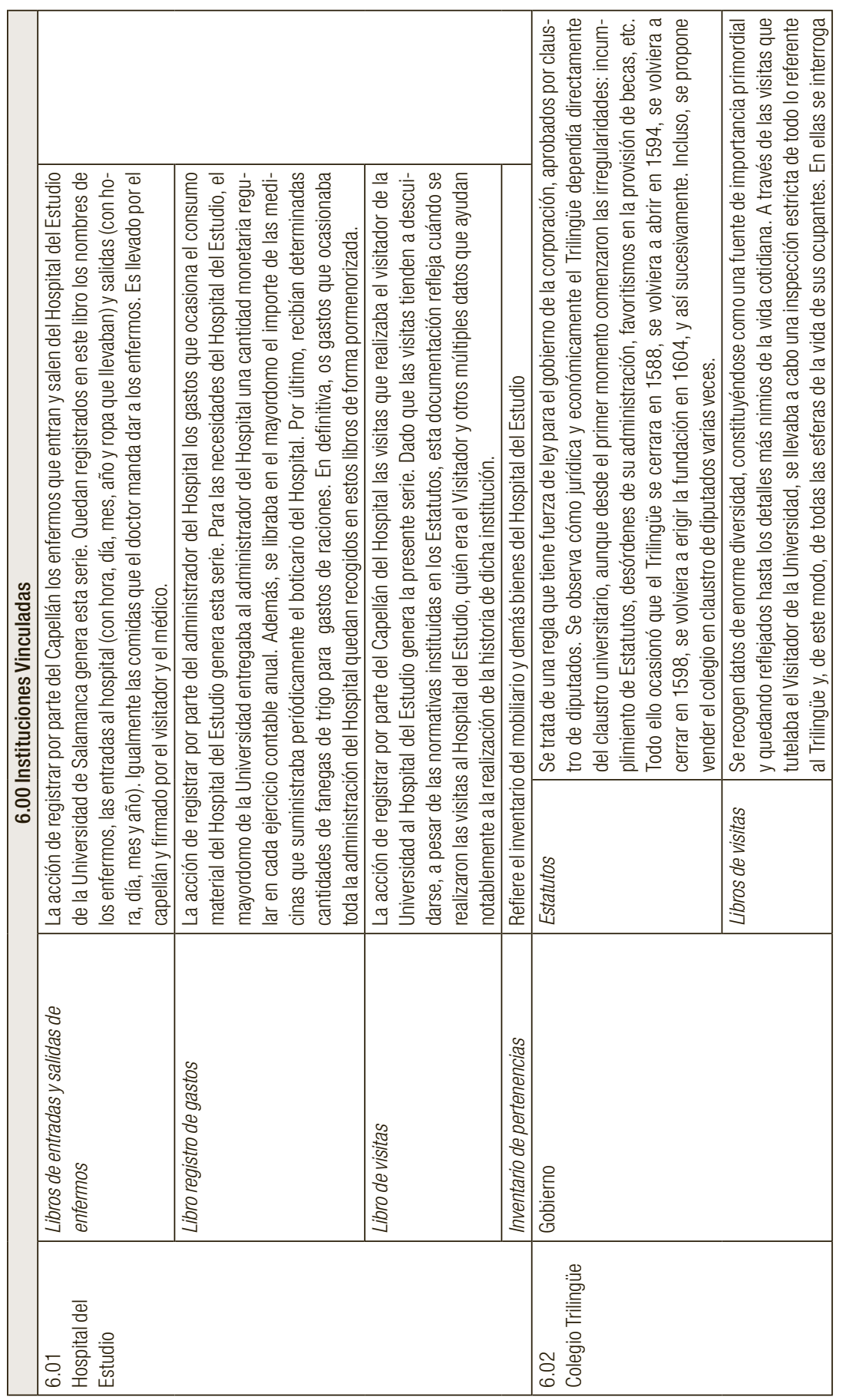




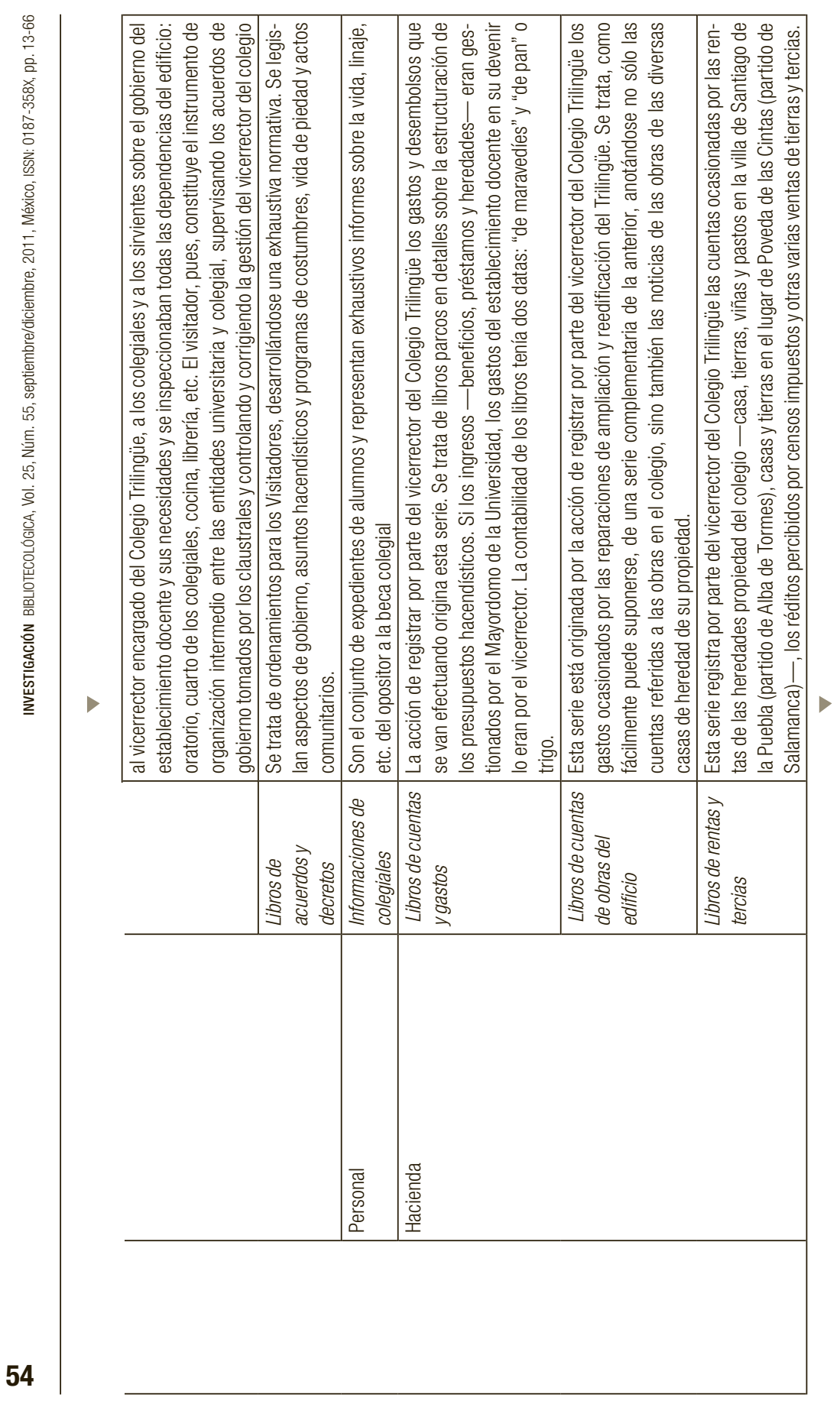




\begin{tabular}{|c|c|c|c|c|}
\hline 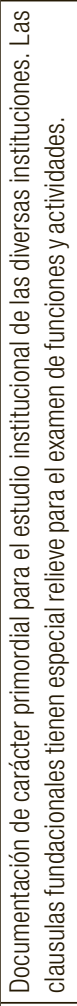 & 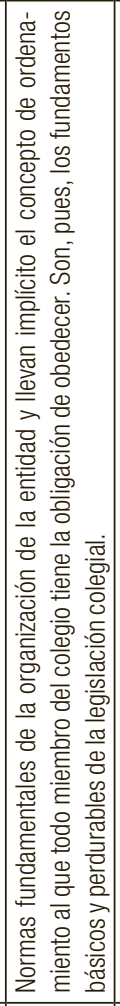 & 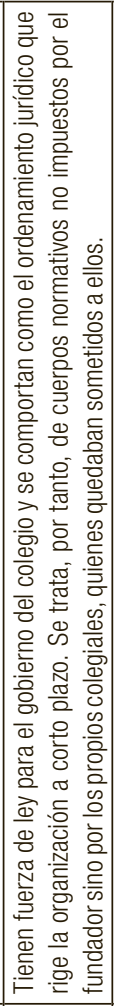 & 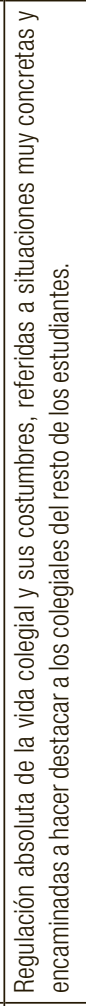 & 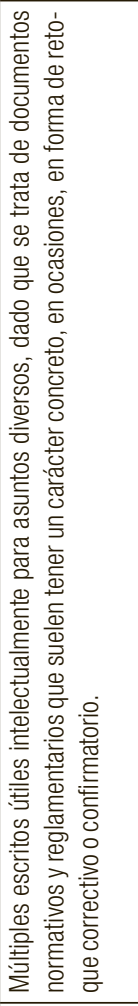 \\
\hline 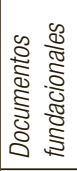 & 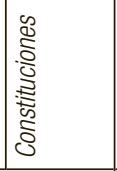 & $\begin{array}{l}\text { O } \\
\text { 壳 } \\
\text { 岕 } \\
\end{array}$ & 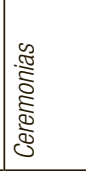 & 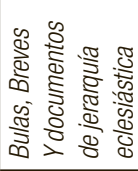 \\
\hline & & & & \\
\hline 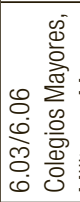 & 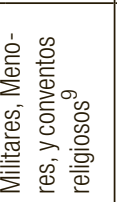 & & & \\
\hline
\end{tabular}

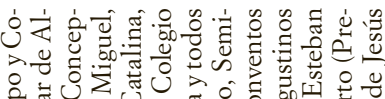
员

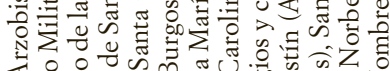
之.․․ำ

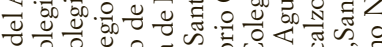

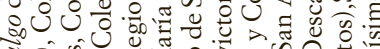
ลิ่ 年

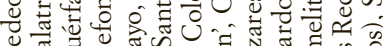

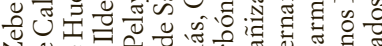
N

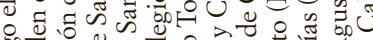

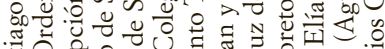
$\exists$ 艾. กี ช 0000

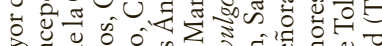
ใับ

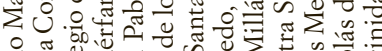
\%

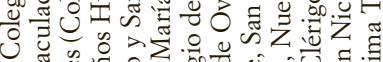

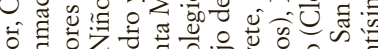

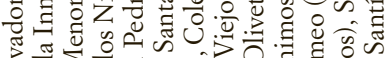

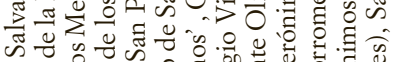

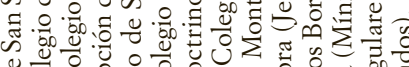
- $00 \% 0$ - U

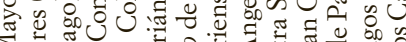
$\sum$ ज. o.

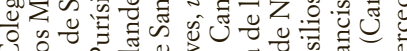

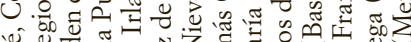

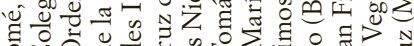

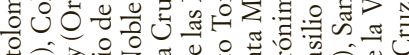

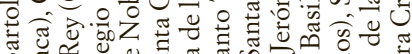
ติ

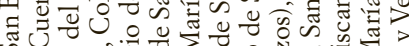

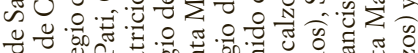
0 讨

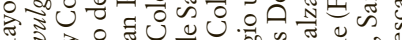

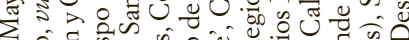
क力

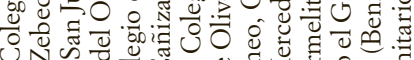
UN $\mathcal{N}$ 我

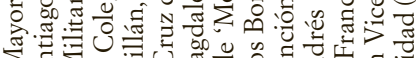

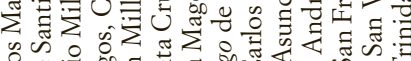

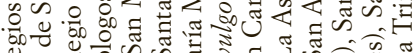

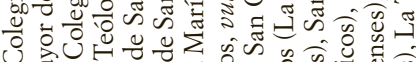

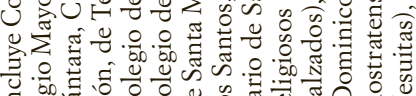

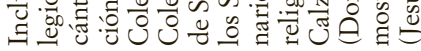




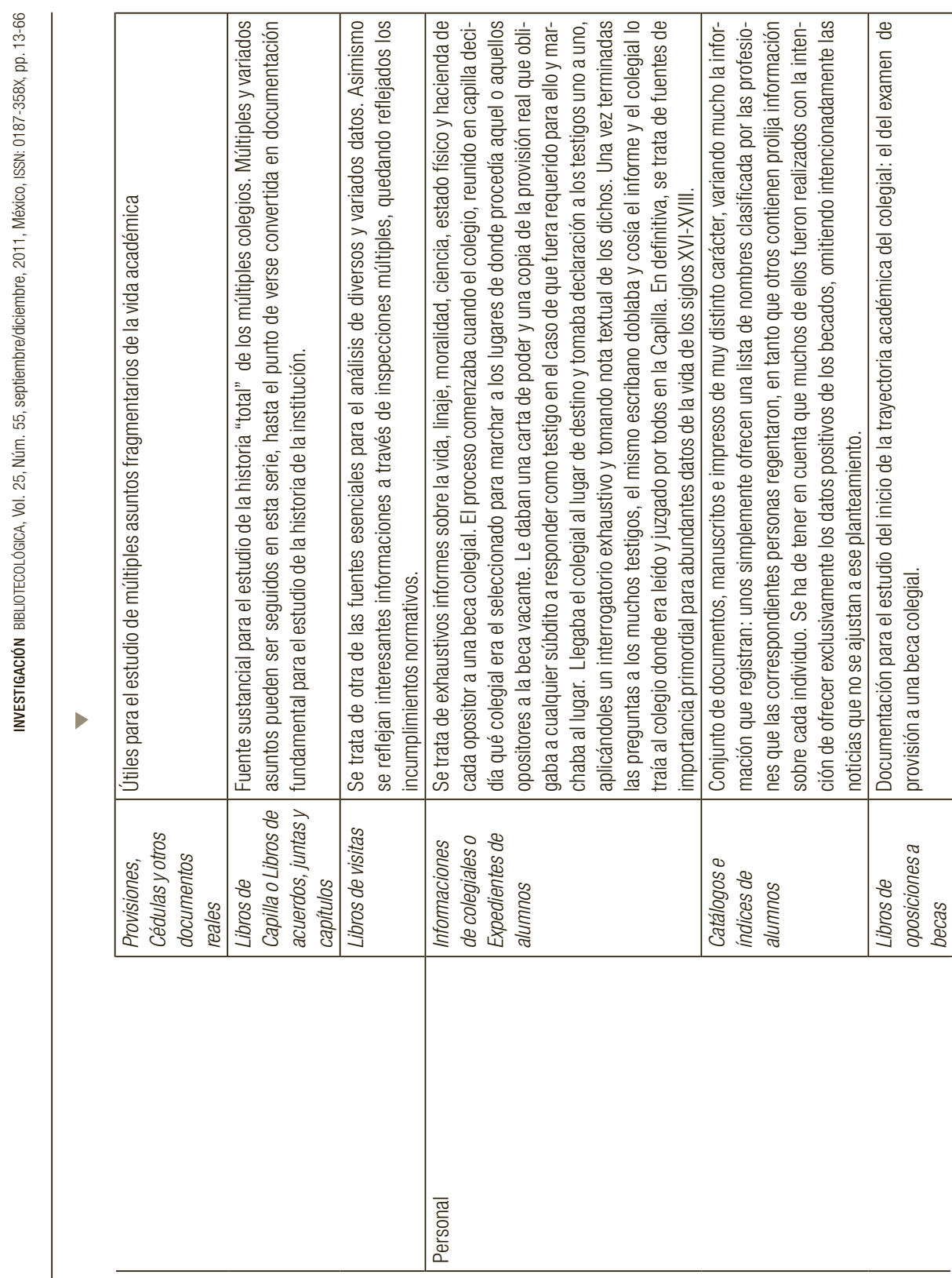


SERIES DOCUMENTALES PARA LA INVESTIGACIÓN EN HISTORIA ...

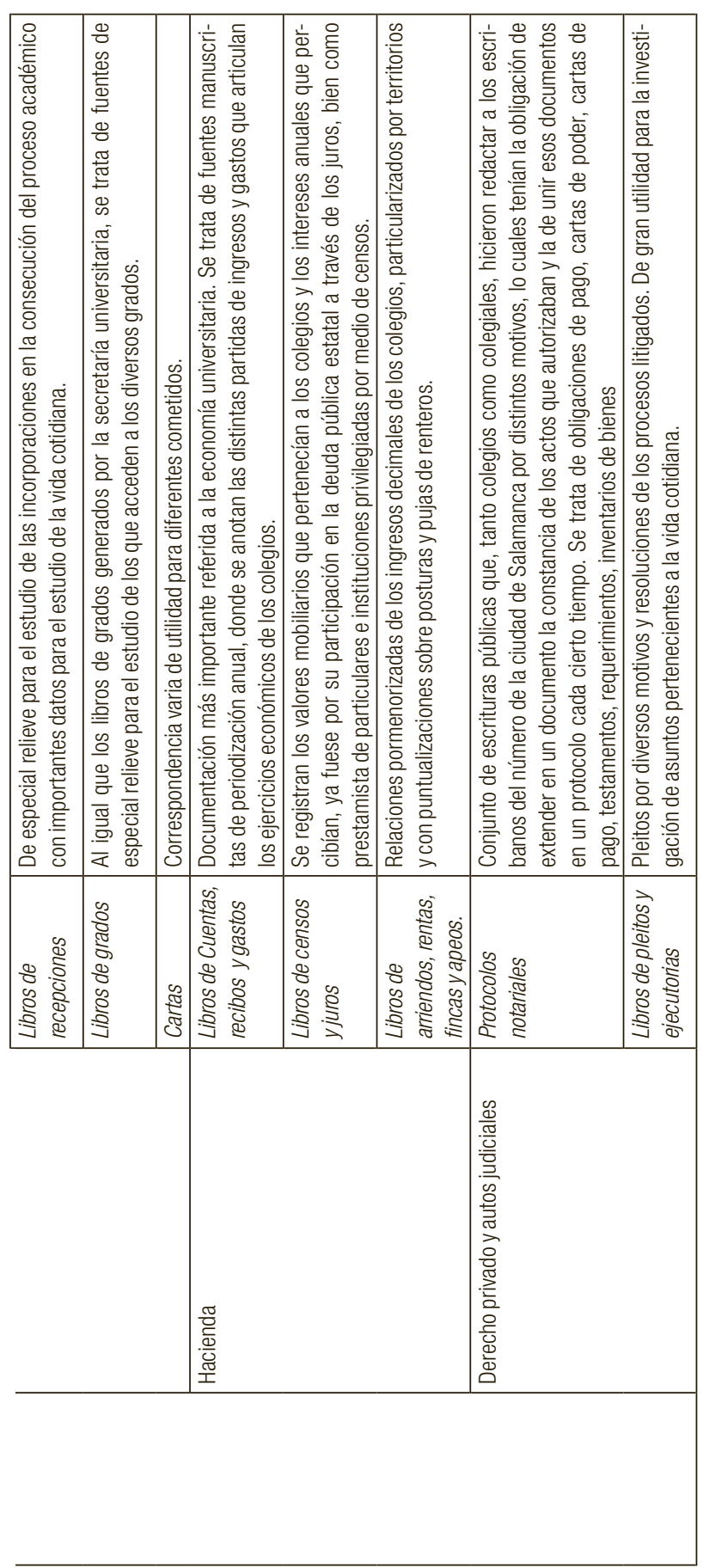




\section{Conclusiones}

1. Las instituciones universitarias españolas han pasado por las siguientes etapas históricas en su devenir: una primera medieval o de afianzamiento que tiene como característica principal su regionalización, esto es, la vinculación de las universidades emergentes a los reinos; una segunda o clasicista que da como resultado grandes universidades al servicio del Estado Moderno recién instaurado y de la Iglesia católica, además de gozar de una amplia proyección por las Indias hispanas; una tercera contemporánea y centralista, donde las universidades vuelven a regionalizarse, y se convierten de nuevo en universidades de distrito; una cuarta o de expansión universitaria con un incremento de universidades sin precedente, una diversificación de facultades y titulaciones y un fuerte incremento de alumnos con una multitudinaria presencia femenina en las aulas; y una quinta caracterizada por el proyecto homogeneizador europeo que queda por determinar en sus reales consecuencias y que persigue un modelo europeo unificado

2. Los archivos universitarios han pasado por las siguientes fases: una primera, vinculada a la doctrina jurídica-administrativa, una segunda más centrada en los aspectos historiográficos y una tercera de amplias consolidaciones científicas. Durante este escueto recorrido por la archivística en las universidades se constata cómo paulatinamente se asiste al proceso de construcción de un campo de saber científico propio y específico, basado, bajo nuestro criterio, en al menos dos ejes de evolución: por un lado, el paso del pragmatismo al conocimiento científico del fenómeno archivístico; esto es, de práctica a ciencia, donde el lenguaje propio, la problemática construida, y los principios científicos originales han resultado ser componentes imprescindibles para la construcción de un saber archivístico que se consolida paulatinamente; y por otro, la pausada incorporación de la archivística universitaria a los procesos informativo-documentales.

3. Nuestro modelo de clasificación para la documentación histórica universitaria reúne las siguientes secciones documentales: Gobierno y poder, reservada a las funciones directivas de la Universidad, repartidas entre autoridad pontificia, autoridad real y claustros académicos; Secretaría, limitando su actuación a la labor docente y discente, esto es, al estudio de la trayectoria estudiantil (matriculación, probanza de cursos, exámenes, incorporaciones, bachilleramientos, licenciamientos y doctoramientos, y visitas de pupilajes y hospedajes) y la trayectoria docente (oposición de cátedras, provisión de cátedras, visitas de 
cátedras, y ausencias y jubilaciones de catedráticos); Hacienda, naturalmente ocupada por la función hacendística, esto es, todo lo relativo a ingresos, gastos y balances; Protocolo y Ceremonia, ocupada por la función protocolaria y ceremonial de la Universidad, esto es, usos y costumbres formales, rituales académicos y protocolo tradicional; Maestrescuela, Audiencia escolástica y pleitos, reservada a las funciones del Maestrescuela y su Audiencia y lo concerniente a aspectos judiciales universitarios; e Instituciones Vinculadas reservada a las funciones que desempeñan las instituciones vinculadas en el marco general de la institución universitaria.

4. Las series documentales de mayor importancia para la investigación en historia de las universidades hispanas aparecen reseñadas en la tabla antes expuesta. Señalar que son de aplicación, aunque estén basadas en el estudio Salmantino, para toda las universidades hispanas por cuanto las Constituciones y Estatutos de la Salmantina fueron calcadas por cuantiosas universidades peninsulares y la inmensa mayoría de las instituciones docentes americanas.

\section{BiBLIOGRAFÍA}

Asociación de Archiveros franceses, Manuel d'Archivistique, París, 1970.

Alberch i Fugueras, R., Els arxius historics municipals: normed basiques de classificació, Barcelona, 1962.

Alejo Montes, F. Javier, La Universidad de Salamanca bajo Felipe II: 1575-1598, [Valladolid], Junta de Castilla y León, 1988.

Alonso Romero, Mª. P., Universidad y sociedad corporativa. Historia del privilegio jurisdiccional del Estudio salmantino, Madrid: Tecnos, 1997.

Arribas Arranz, F., "El Archivo Histórico Provincial y Universitario de Valladolid", RABM, 65(1958), pp. 261-271.

Canellas López, A., "El Archivo de la Universidad de Zaragoza en 1770”, Jerónimo Zurita. Cuadernos de Historia, vol. 45 (1983), pp. 115-149.

Carabias Torres, A. M., Colegios Mayores: Centros de Poder. Los Colegios Mayores de Salamanca durante el siglo XVI, Salamanca, 1986, 3 vols.

, El Colegio Mayor de Cuenca en el siglo XVI: Estudio institucional. Salamanca: Univversidad, 1986.

Carmona De Los Santos, Ma., "La Universidad Central y su distrito: fondos documentales en el Archivo Histórico Nacional", Boletín de la ANABAD, XLVI (1996), pp. 167-190. 
Corons, D., "El Archivo de la Universidad Complutense de Madrid", BANABAD, vol. XXVIII, núm 3 (1978), pp. 33-40.

Fernández Álvarez, M.; Robles Carcedo, L.; y Rodríguez-San Pedro Bezares, L.E. (Coords.), La Universidad de Salamanca, Salamanca: Universidad de Salamanca, 3 vols. Vol. II, 1990.

Fernández Hidalgo, Mª del C. y García Ruipérez, M., "La clasificación en los archivos municipales españoles: evolución histórica y situación actual”, en Irargi. Revista de Archivística, II (1989), pp. 133-349.

Lapresa Molina, E. de, "El Archivo de la universidad de Granada a través de sus inventarios", en Boletín de la Universidad de Granada, II época, 1953, tomo II, pp. 53-58.

Lladó y Ferragut, J., El Archivo de la Real y Pontificia Universidad Literaria y Estudio general Luliano de antiguo Reino de Mallorca, Palma de Mallorca: Ferrer, 1946.

Llamas Martínez, E., Archivo y Biblioteca de la Universidad Pontificia de Salamanca, Salamanca: Universidad Pontificia, 1990.

Méndez Sanz, F., La Universidad Salmantina de la Ilustración, 1750 1800: Hacienda y Reforma, Salamanca: Universidad de Salamanca, 1988.

Mendo Carmona, C., "El largo camino de la Archivística: de práctica a ciencia", SIGNO, en Revista de Historia de la Cultura Escrita. Núm. 2 (1995), pp. 113-132.

Moralejo Álvarez, $\mathrm{M}^{\mathrm{a}} \mathrm{R}$., "Archivo Universitario de Zaragoza", en Actas de las IV Jornadas de Archivos Aragoneses, Zaragoza: Diputación General de Aragón, 1994, pp. 181-193.

Peset Reig, M., "Los archivos universitarios: su contenido y sus posibilidades", en Estudios en recuerdo de la profesora Sylvia Romeu Alfaro, Valencia: Universidad, 1989, T. II, pp. 759-772.

Peset Reig, M.; Peset Reig, J.L., La Universidad española. Siglos XVIII y XIX. Despotismo ilustrado y revolución liberal, Madrid, 1974.

Polo Rodríguez, J.L., La Universidad Salmantina del Antiguo Régimen (1700-1750), Salamanca: Universidad de Salamanca, 1995.

Prieto Cantero, A., "Los archivos históricos universitarios españoles. Ensayo de un esquema de organización", en Boletín de la ANABAD, XXIX, 2, p. 221.

Rodríguez Cruz, A., Historia de la Universidades Hispanoamericanas. Periodo Hispánico, Bogotá, 1973, 2 vols.

, Salmantica docet. La proyección de la Universidad de Salamanca en Hispanoamérica, Salamanca, 1977.

Rodríguez De Diego, J.L., "Archivos del Poder, archivos de la administración, archivos de la Historia”, en Generelo, J.J. y Moreno López, Á. (Coords.). Historia de los Archivos y de la Archivística en España, Valladolid: Universidad de Valladolid, 1998, pp. 29-42. 
"La formación del Archivo de Simancas en el s. XVI. Función y orden interno", en López Vidriero, $M^{a}$ L. y Cátedra, P. El libro Antiguo Español IV. Coleccionismo y biblioteca. Siglos XV-XVIII, Salamanca: Universidad de Salamanca, Patrimonio Nacional, Sociedad Española de Historia del Libro, 1998, pp. 519-557.

Rodríguez-San Pedro Bezares, L.E., La Universidad Salmantina del Barroco, periodo 1598-1625, Tesis doctoral, Salamanca: Universidad de Salamanca y Caja de Ahorros de Salamanca, 3 vols., 1986.

, "La Universidad de Salamanca, evolución y declive de un modelo clásico", en Studia Histórica.Historia Moderna IX, 1991, 921.

, "Las Universidades de Castilla", en Historia de una cultura: la singularidad de Castilla, Valladolid: Junta de Castilla y León, 1995, Tomo II, pp. 411-459; y “Universidades en Castilla y León”, Tomo IV, pp. 403-423

, Historia de la Universidad de Salamanca. Salamanca: Universidad de Salamanca, 6 vols. 1999-2009.

Santander Rodríguez, T., "Fuentes para una Historia de la Universidad de Salamanca”, en Fernández Álvarez, M.; Rodríguez San Pedro Bezares, L.E.; y Robles Carcedo, L. (Coords.) La Universidad de Salamanca, Vol. II: Docencia e Investigación, Salamanca: Universidad de Salamanca, 1990, pp. 297-312.

Sotelo Martín, Mª E., El Archivo Histórico de la Universidad de Alcalá, Alcalá de Henares: Ulzama Digital, 2003.

Vivas Moreno A., El Archivo Histórico de la Universidad de Salamanca: Historia y clasificación de sus fondos documentales, Gijón: Trea, 2003.

Vivas Moreno, A., "El tiempo de la Archivística: un estudio de sus espacios de racionalidad histórica”, en Ciência da informaçao, 33, 3 , (2004), pp. 76-97. 


\title{
APÉNDICE 1.
}

\author{
GARE Y GARR
}

\begin{abstract}
Comparación de los textos de las directrices GARE y GARR para ver los cambios introducidos al adaptar las primeras al modelo FRBR (En letra cursiva están destacadas las variaciones)
\end{abstract}

\subsection{Registros de autoridad}

\section{GARE. Entrada de autoridad}

1. Área de encabezamiento de autoridad: encabezamiento uniforme y paralelos. Puede afectar a una persona, entidad u obra. Puede ir acompañado de subelementos del nombre y de adiciones a éste.

Para los nombres de entidades cuya forma oficial puede estar compartida en varias lenguas y para los títulos de clásicos anónimos, se puede crear más de una entrada de autoridad, usando un encabezamiento de autoridad para cada forma del lenguaje del nombre.

2. Área de nota de información Para explicar la relación entre el encabezamiento de autoridad y las citas de referencia.

Pueden consistir en:

1. explicación de la relación entre dos encabezamiento de nombres de persona.

2. historia de una entidad en relación a los cambios de nombre.

3. explicación de los encabezamientos de partes de obras con el de la obra completa.

Son notas destinadas a los usuarios, que pueden aparecer en un catálogo o bibliografía.

3. Area de cita de referencia de "Véase" Sirve como un registro de los encabezamientos alternativos para lo que se ha construido la entrada de referencia, dirigiendo al usuario a ver el encabezamiento autorizado.

4. Área de cita de referencia de "Véase además" Sirve como un registro de los encabezamientos relacionados a los que se han hecho entradas de referencia, para dirigir al usuario a ver además el encabezamiento autorizado

\section{GARR. Registro de autoridad}

1. Área de encabezamiento de autoridad: encabezamiento autorizado y paralelos. Puede afectar a una persona, entidad u obra/expresión. Puede ir acompañado de subelementos del nombre y de calificadores.

Para los nombres de entidades cuya forma oficial puede estar compartida en varias lenguas y para los títulos que pueden presentar varias formas de redacción en más de una lengua, se puede crear más de un registro de autoridad, dando el encabezamiento autorizado a cada uno en la lengua correspondiente

2. Área de nota de información

Para explicar la relación entre el encabezamiento autorizado y los trazados de referencia o para precisar la identificación del encabezamiento autorizado.

Pueden consistir en:

1. explicación de la relación entre dos encabezamiento de nombres de persona.

2. historia de una entidad en relación a los cambios de nombre.

3. explicación de los encabezamientos de partes de obras con el de la obra completa.

4. información para identificar la entidad que encabeza (persona, institución, etc.)

Son notas destinadas a los usuarios, que pueden aparecer en un catálogo o bibliografía.

3. Área de trazado de referencia de "Véase"

Sirve como una relación de los encabezamientos variantes para los que se han hecho asientos de referencia, los cuales encaminan al usuario a consultar el encabezamiento autorizado

4. Área de trazado de referencia "Véase también" Sirve como un registro o lista de los encabezamiento relacionados para los que se han hecho asientos de referencia, para dirigir al usuario a consultar también el encabezamiento autorizado. 


\begin{tabular}{|l|l|}
\hline $\begin{array}{l}\text { 5. Área de nota del catalogador } \\
\begin{array}{l}\text { De uso interno, pueden incluir notas sobre las } \\
\text { fuentes consultadas, normas empleadas, justifi- } \\
\text { cación de la elección del nombre, etc. }\end{array}\end{array}$ & $\begin{array}{l}\text { 5. Área de nota del catalogador } \\
\text { De uso interno, pueden incluir notas sobre las } \\
\text { fuentes consultadas, normas empleadas, justifi- } \\
\text { cación de la elección del nombre, etc. }\end{array}$ \\
\hline $\begin{array}{l}\text { 6. Área de fuente } \\
\text { Agencia catalogadora, normas empleadas y fecha } \\
\text { de la creación de la entrada }\end{array}$ & $\begin{array}{l}\text { 6. Área de fuente } \\
\text { Agencia catalogadora, normas empleadas y fecha } \\
\text { de la creación de la entrada }\end{array}$ \\
\hline 7. Área del ISADN & 7. Área del ISADN \\
\hline
\end{tabular}

\subsection{Registros de referencia}

\begin{tabular}{|l|l|}
\hline \multicolumn{1}{|c|}{ GARE. Entrada de referencia } & \multicolumn{1}{c|}{ GARR. Asiento de referencia } \\
\hline $\begin{array}{l}\text { Sirve para dirigir al usuario desde un encabezamiento } \\
\text { alternativo o relacionado al encabezamiento(s) uni- } \\
\text { forme apropiado. }\end{array}$ & $\begin{array}{l}\text { Sirve par dirigir al usuario desde un encabezamiento } \\
\text { variante o relacionado a los encabezamientos autori- } \\
\text { zados que se precisen }\end{array}$ \\
\hline $\begin{array}{l}\text { 1. Área de encabezamiento de referencia } \\
\text { Contiene un encabezamiento alternativo o re- } \\
\text { lacionado desde el que se dirige al usuario al } \\
\text { encabezamiento(s) uniforme apropiado. }\end{array}$ & $\begin{array}{l}\text { 1. Área de encabezamiento de referencia } \\
\text { Contiene un encabezamiento variante o rela- } \\
\text { cionado desde el que se dirige al usuario al } \\
\text { encabezamiento(s) autorizados a los que procede } \\
\text { hacerlo. }\end{array}$ \\
$\begin{array}{l}\text { 2. Área de nota de información } \\
\text { Para explicar, cuando sea necesario, las relacio- } \\
\text { nes entre el encabezamiento de referencia y el } \\
\text { encabezamiento(s) uniforme }\end{array}$ & $\begin{array}{l}\text { 2. Área de nota de información } \\
\text { Para explicar, cuando sea necesario, las relacio- } \\
\text { nes entre el encabezamiento de referencia y el } \\
\text { encabezamiento(s) autorizado }\end{array}$ \\
$\begin{array}{l}\text { 3. Área de encabezamiento uniforme } \\
\text { Para dirigir al usuario al encabezamiento(s) unifor- } \\
\text { me apropiado }\end{array}$ & $\begin{array}{l}\text { 3. Área del encabezamiento autorizado } \\
\text { Para dirigir al usuario al correspondiente encabe- } \\
\text { zamiento(s) autorizado }\end{array}$ \\
\hline
\end{tabular}

\subsection{Registros Explicativos}

\begin{tabular}{|l|c|}
\hline \multicolumn{1}{|c|}{ GARE. Entrada general explicativa } & GARR. Registros y asientos explicativos generales \\
\hline $\begin{array}{l}\text { 1. Área de encabezamiento explicativo. } \\
\begin{array}{l}\text { Contiene un encabezamiento parcial, estilizado } \\
\text { o ejemplarizado desde el que se dirige al usua- } \\
\text { rio a una clase general o a una categoría defini- } \\
\text { da de encabezamientos. }\end{array}\end{array}$ & $\begin{array}{r}\text { 1. Área de encabezamiento explicativo. } \\
\text { Contiene un encabezamiento parcial, abreviado o } \\
\text { explicativo desde el que se dirige al usuario a una } \\
\text { clase general o a una categoría definida de enca- } \\
\text { bezamientos. }\end{array}$ \\
\hline $\begin{array}{l}\text { 2. Área de nota de información } \\
\text { Información sobre las convenciones usadas al } \\
\text { formular u ordenar los encabezamientos que el } \\
\text { usuario puede encontrar bajo la formadaza en } \\
\text { el encabezamiento explicativo }\end{array}$ & $\begin{array}{l}\text { 2. Área de nota de información } \\
\text { Información respecto a las convenciones utilizadas } \\
\text { al formular u ordenar los encabezamientos autori- } \\
\text { zados que es previsible encontrar en la forma dada } \\
\text { en el encabezamiento explicativo }\end{array}$ \\
\hline $\begin{array}{l}\text { 3. Área de fuente } \\
\text { Agencia catalogadora, normas empleadas y fe- } \\
\text { cha de la creación de la entrada explicativa }\end{array}$ & $\begin{array}{l}\text { 3. Área de fuente } \\
\text { Agencia catalogadora, normas empleadas y fecha } \\
\text { de la creación de la entrada }\end{array}$ \\
\hline $\begin{array}{l}\text { 4. Área del ISADN de la entrada general } \\
\text { explicativa }\end{array}$ & 4. Área del ISADN de la entrada general explicativa \\
\hline
\end{tabular}




\section{APÉNDICE 2}

Esquema del modelo FRAD (basado en el borrador actualizado en 2007).

Los atributos precedidos del signo + no aparecen en el modelo FRBR para los registros bibliográficos.

\begin{tabular}{|c|c|c|}
\hline Entidades & Contenido & Atributos \\
\hline $\begin{array}{l}\text { Persona } \\
\text { Individuo o persona establecida } \\
\text { por un individuo o grupo }\end{array}$ & $\begin{array}{l}\text { Persona real o ficticia } \\
\text { Un nombre que agrupa a dos } \\
\text { personas }\end{array}$ & $\begin{array}{l}\text { Fechas } \\
\text { Títulos asociados a la persona \$c } \\
\text { Otra designación asociada a la } \\
\text { persona (otro \$c) } \\
\text { +Sexo } \\
\text { +Lugar de nacimiento y muerte } \\
\text { +País (con el que se identifica) } \\
\text { +Lugar de residencia } \\
\text { +Afiliación (trabajo, cultural,...) } \\
\text { +Dirección (puede ser una URL) } \\
\text { +Lengua (en la que escribe) } \\
\text { +Campo de actividad } \\
\text { +Profesión/ocupación } \\
\text { +Biografía/historia }\end{array}$ \\
\hline $\begin{array}{l}\text { Familia } \\
\text { Dos o más personas con relación } \\
\text { familiar o que se presenten como } \\
\text { una familia }\end{array}$ & $\begin{array}{l}\text { Familias reales, dinastías, casas } \\
\text { de nobleza } \\
\text { Unidades familiares... }\end{array}$ & $\begin{array}{l}\text { Tipo de familia (dinastía, matriarcado... }) \\
\text { Fechas asociadas a la familia } \\
\text { Lugares asociados a la familia } \\
\text { Historia de la familia }\end{array}$ \\
\hline $\begin{array}{l}\text { Entidad corporativa } \\
\text { Grupo de personas u organiza- } \\
\text { ción que actúa como una unidad }\end{array}$ & $\begin{array}{l}\text { Son conocidas por un nombre } \\
\text { Congresos, conferencias, expo- } \\
\text { siciones... } \\
\text { Grupos musicales, artisticos... } \\
\text { Organizaciones gubernamentales }\end{array}$ & $\begin{array}{l}\text { Lugar asociado } \\
\text { Fechas asociadas } \\
\text { Otra designación asociada } \\
\text { +Tipo de e.c. (gubernamental, } \\
\text { conferencia...) } \\
\text { +Lengua } \\
\text { +Dirección } \\
\text { +Campo de actividad } \\
\text { +Historia } \\
\end{array}$ \\
\hline $\begin{array}{l}\text { Obra } \\
\text { Cada creación intelectual } 0 \\
\text { artística distinta }\end{array}$ & $\begin{array}{l}\text { Individuales o colectivas } \\
\text { En cualquier medio } \\
\text { Con cualquier contenido }\end{array}$ & $\begin{array}{l}\text { Forma (forma, géneros...) } \\
\text { Fecha (la primera asociada a ella) } \\
\text { Medio de ejecución (música) } \\
\text { +Tema de la obra } \\
\text { Designación numérica } \\
\text { Clave (música) } \\
\text { +Lugar de origen } \\
\text { +Lengua original } \\
\text { +Historia } \\
\text { Otras características distintivas } \\
\text { (para diferenciar la obra de otra de } \\
\text { igual título) }\end{array}$ \\
\hline $\begin{array}{l}\text { Expresión } \\
\text { Realización intelectual o artística } \\
\text { de una obra por cualquier medio } \\
\text { y en cualquier lengua }\end{array}$ & $\begin{array}{l}\text { Incluye traducciones, versiones y } \\
\text { adaptaciones }\end{array}$ & $\begin{array}{l}\text { Forma de expresión (medio/s) } \\
\text { Fecha (de creación de la expresión) } \\
\text { Lengua/s } \\
\text { Técnica (imagen fija y animada) } \\
\text { Otras características distintivas } \\
\text { (para diferenciar la expresión de otra } \\
\text { de igual título) }\end{array}$ \\
\hline
\end{tabular}




\begin{tabular}{|c|c|c|}
\hline $\begin{array}{l}\text { Manifestación } \\
\text { La plasmación física de una } \\
\text { expresión de una obra }\end{array}$ & $\begin{array}{l}\text { Forma de presentación: revista, } \\
\text { libro... } \\
\text { Forma: película, DVD, ... } \\
\text { Puede ser única: un manuscrito } \\
\text { Incluye toda la tirada }\end{array}$ & \begin{tabular}{|l} 
Edición \\
Lugar de publicación \\
Editor \\
Fecha de publicación \\
Formato (casette, videodisco, \\
cartucho de microfilm) \\
Numeración (en las series)
\end{tabular} \\
\hline $\begin{array}{l}\text { Item } \\
\text { Cada ejemplar de la manifes- } \\
\text { tación }\end{array}$ & $\begin{array}{l}\text { Puede ser de más de un volumen, } \\
\text { en las obras en varios volúmenes }\end{array}$ & $\begin{array}{l}\text { +Localización (biblioteca y signatura } \\
\text { topográfica) }\end{array}$ \\
\hline $\begin{array}{l}\text { Concepto } \\
\text { Una idea o noción abstracta }\end{array}$ & $\begin{array}{l}\text { Campos de conocimiento, } \\
\text { disciplinas } \\
\text { Filosofía, religiones, ideas } \\
\text { políticas } \\
\text { Teorías , procesos, técnicas... } \\
\text { Categorías de personas, pueblos, } \\
\text { especies biológicas, clases de } \\
\text { objetos... }\end{array}$ & $\begin{array}{l}\text { +Tipo de concepto (categorización o } \\
\text { descripción genérica del concepto de } \\
\text { acuerdo con el sistema de clasifica- } \\
\text { ción o thesauro utilizado) }\end{array}$ \\
\hline $\begin{array}{l}\text { Objeto } \\
\text { Una cosa material }\end{array}$ & $\begin{array}{l}\text { Objetos inanimados } \\
\text { Animales, plantas (pero no las } \\
\text { especies) } \\
\text { Objetos móviles y no móviles } \\
\text { creados por el hombre }\end{array}$ & $\begin{array}{l}\text { +Tipo de objeto (categorización o } \\
\text { descripción genérica del concepto de } \\
\text { acuerdo con el sistema de clasifica- } \\
\text { ción o thesauro utilizado) } \\
\text { +Fecha de producción } \\
\text { +Lugar de producción } \\
\text { +Productor/fabricante } \\
\text { +Medio físico (material) }\end{array}$ \\
\hline $\begin{array}{l}\text { Acontecimiento } \\
\text { Una acción u ocurrencia }\end{array}$ & $\begin{array}{l}\text { Acontecimientos históricos, } \\
\text { deportivos, épocas, eras } \\
\text { Periodos de tiempo históricos, } \\
\text { culturales, artísticos } \\
\text { Expediciones, encuentros (en } \\
\text { algunas RC son entidades } \\
\text { corporativas) }\end{array}$ & $\begin{array}{l}\text { +Fechas asociadas } \\
\text { +Lugar asociado }\end{array}$ \\
\hline $\begin{array}{l}\text { Lugar } \\
\text { Una localización }\end{array}$ & $\begin{array}{l}\text { Terrestre o extraterrestre } \\
\text { Históricos y futuros } \\
\text { Geográficos: montes, ríos... } \\
\text { Países o jurisdicciones }\end{array}$ & $\begin{array}{l}\text { +Coordenadas } \\
\text { +Otra información geográfica }\end{array}$ \\
\hline $\begin{array}{l}\text { Nombre } \\
\text { Carácter/es o palabra/s por las } \\
\text { que una entidad es conocida }\end{array}$ & $\begin{array}{l}\text { De personas, organizaciones y } \\
\text { familias } \\
\text { De títulos de obras, expresiones y } \\
\text { manifestaciones } \\
\text { De conceptos, objetos, aconteci- } \\
\text { mientos y lugares } \\
\text { Nombres reales, seudónimos, } \\
\text { religiosos... }\end{array}$ & $\begin{array}{l}\text { Tipo de nombre (personal, } \\
\text { corporativo, familia, expresiones y } \\
\text { manifestaciones) } \\
\text { Alcance de uso (la forma de la obra } \\
\text { asociada a un particular nombre de } \\
\text { persona: obras, literarias, críticas, } \\
\text { novelas policíacas, obras matema- } \\
\text { ticas...) } \\
\text { Fechas de uso } \\
\text { Lengua del nombre (en el que está } \\
\text { expresado) } \\
\text { Escritura del nombre } \\
\text { Esquema de transliteración (si se } \\
\text { ha hecho) }\end{array}$ \\
\hline
\end{tabular}




\begin{tabular}{|c|c|c|c|}
\hline$>$ & $\begin{array}{l}\text { Identificador } \\
\text { Número, código, palabra, frase... } \\
\text { que es únicamente asociada con } \\
\text { una entidad y la diferencia de otra }\end{array}$ & $\begin{array}{l}\text { Número de registro de empresas } \\
\text { y organizaciones } \\
\text { Números normalizados de las } \\
\text { distintas manifestaciones } \\
\text { Una entidad puede tener varios }\end{array}$ & $\begin{array}{l}\text { Tipo de identificador (códigos, } \\
\text { ISBN,...) } \\
\text { Condición (registro de marca, } \\
\text { caracteres que lo diferencia de otros } \\
\text { en su dominio) } \\
\text { Sufijo (caracteres que completan la } \\
\text { condición) }\end{array}$ \\
\hline & $\begin{array}{l}\text { Punto de acceso controlado } \\
\text { Nombre, término, código... bajo } \\
\text { el cual un registro bibliográfico } 0 \\
\text { de autoridad puede ser buscado } \\
\text { (GARR) }\end{array}$ & $\begin{array}{l}\text { Punto de acceso autorizado y } \\
\text { variante } \\
\text { De personas, familias, títulos, } \\
\text { autor-título }\end{array}$ & $\begin{array}{l}\text { Tipo (persona, familia..., título } \\
\text { uniforme, congreso...) } \\
\text { Estatus (provisional...) } \\
\text { Designación de uso (forma preferen- } \\
\text { te o variante) } \\
\text { No diferenciado (no diferencia } \\
\text { claramente varias entidades de un } \\
\text { mismo nombre) } \\
\text { Lenguaje del fichero o base de datos } \\
\text { Lengua de la catalogación } \\
\text { Escritura del fichero o base de datos } \\
\text { Escritura de la catalogación } \\
\text { Esquema de transliteración de la } \\
\text { base de datos } \\
\text { Esquema de transliteración de la } \\
\text { catalogación } \\
\text { Fuente (obra de referencia usada } \\
\text { para establecer la forma) } \\
\text { Punto de acceso base (todos los } \\
\text { elementos integrados en la forma del } \\
\text { punto de acceso) } \\
\text { Adición (palabras añadidas al p. de } \\
\text { a. base: rey, papa...) } \\
\end{array}$ \\
\hline & $\begin{array}{l}\text { Reglas } \\
\text { El conjunto de instrucciones } \\
\text { relativas a la formulación y/0 } \\
\text { registro de los puntos de acceso } \\
\text { controlados }\end{array}$ & $\begin{array}{l}\text { Punto de acceso autorizado y } \\
\text { referencias } \\
\text { Reglas de catalogación }\end{array}$ & $\begin{array}{l}\text { Cita de las reglas de catalogación } \\
\text { usadas } \\
\text { Identificador de las reglas (acrónimo } \\
\text { o código alfanumérico) }\end{array}$ \\
\hline & $\begin{array}{l}\text { Agencia } \\
\text { La organización responsable } \\
\text { de crear o modificar el punto de } \\
\text { acceso }\end{array}$ & & $\begin{array}{l}\text { Nombre de la agencia } \\
\text { Identificador de la agencia } \\
\text { Localización }\end{array}$ \\
\hline
\end{tabular}

